\title{
Provenance of the Ciénaga de Oro Formation: unveiling the tectonic evolution of the Colombian Caribbean margin during the Oligocene - Early Miocene
}

\author{
Alejandra Manco-Garcés ${ }^{1 *}$ (D) ; Maria Isabel Marín-Cerón ${ }^{1}$ (D) ; Carlos Javier Sánchez-Plazas ${ }^{2}$ (D) ; \\ Luis Carlos Escobar-Arenas ${ }^{1}$ (D) ; Alejandro Beltrán-Triviño ${ }^{1}$ (D) ; Albrecht von Quadt ${ }^{3}$
}

How to cite: Manco-Garcés, A.; Marín-Cerón, M.I.; Sánchez-Plazas, C.J.; Escobar-Arenas, L.C.; BeltránTriviño, A.; von Quadt, A. (2020). Provenance of the Ciénaga de Oro Formation: unveiling the tectonic evolution of the Colombian Caribbean margin during the Oligocene - Early Miocene. Boletín de Geología, 42(3), 205-226. https://doi.org/10.18273/revbol.v42n3-2020009

Supplementary material: This article has supplementary material.

\begin{abstract}
A stratigraphic section in the San Jacinto fold and thrust belt located at northwestern Colombia was studied. This section displays part of the Oligocene-Early Miocene Ciénaga de Oro Formation (COF). This work analyses the sediments provenance using a multi-tool approach which include: (I) conglomerate and sandstone counting clast with mesh, (II) heavy minerals assemblages, (III) paleocurrents and (IV) U/Pb detrital zircon ages. The sedimentary sequence was deposited in deltaic to transitional environment deposition, with reduction in the waves and tidal effect, and increase in the dominance of transitional river processes upward the section. Two main source areas have been identified from a dissected arc province: a main granitic to pegmatitic and a secondary basic igneous source rocks, located to the east and southwest of the current position. Detrital zircon U-Pb geochronology analysis display four age populations: (I) Devonian-Permian, (II) Permian-Triassic, (III) Jurassic and (IV) Cretaceous, with maximum deposition ages of $75.2 \pm 0.9$ Ma in the lower part of the section, $68.9 \pm 0.6 \mathrm{Ma}$ in the middle and $74.5 \pm 0.7 \mathrm{Ma}$ for the upper part. It is proposed that COF was sediment-supplied by a south-to-north fluvial system, which drained exposed basement blocks and their late Cretaceous to Paleogene sedimentary cover during the Oligocene. This fluvial system carried sediments from late Cretaceous plutons like the Antioqueño Batholith and mafic/ ultramafic rocks, which make up the basement of the Western and Central Cordilleras.
\end{abstract}

Keywords: Ciénaga de Oro Formation; San Jacinto Fold Belt; Provenance; Heavy minerals; Paleocurrents; Northern South America plate.

\section{Proveniencia de la Formación Ciénaga de Oro: revelando la evolución tectónica del margen Caribe colombiano durante el Oligoceno - Mioceno Temprano}

\begin{abstract}
Resumen
Se realizó el estudio de una sección estratigráfica en el Cinturón Plegado y de Cabalgamiento de San Jacinto, localizado en el noroccidente de Colombia. En esta sección aflora parte de la Formación Ciénaga de Oro del Oligoceno-Mioceno temprano. Este trabajo analiza la procedencia de los sedimentos, utilizando un enfoque de múltiples herramientas que incluye: (I) conteo de clastos de areniscas y conglomerados con malla, (II) minerales pesados, y (III) paleocorrientes y (IV) edades U-Pb de circones detríticos. La secuencia sedimentaria fue depositada en un ambiente deltaico a transicional, con reducción del efecto del oleaje y la marea junto con el incremento de la dominancia de los procesos transicionales de río hacia el tope de la sección. Se identificó dos áreas fuentes de una provincia de arco disectado: principalmente un área fuente de composición granítica a pegmatítica y un área fuente secundaria de composición ígnea a básica, localizadas al este y suroeste de la posición actual de la secuencia. El análisis geocronológico de circones detríticos muestra cuatro poblaciones de edades: (I) Devónico-Pérmico, (II) Pérmico-Triásico, (III) Jurásico y (IV) Cretácico. Las

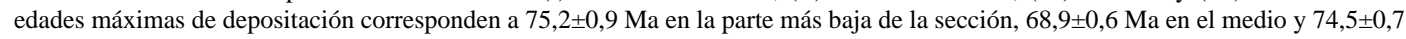
Ma para la parte superior de la sección. Se propone que el material depositado en COF fue suministrado desde sistemas fluviales del sur hacia el norte, que erosionaron bloques de basamento expuesto y su cobertura sedimentaria (Cretácico tardío a Paleógena) durante el Oligoceno. Este sistema fluvial transportó sedimentos desde plutones tipo Batolito Antioqueño del Cretácico Tardío y rocas máficas/ ultramáficas, como las encontradas en las Cordillera Central y Occidental.
\end{abstract}

Palabras clave: Formación Ciénaga de Oro; Cinturón Plegado San Jacinto; Proveniencia; Minerales pesados; Paleocorrientes; Norte de la placa suramericana.

${ }^{1}$ Grupo de Investigación en Geología Ambiental, Escuela de Ciencias, Universidad EAFIT, Medellín, Colombia. (*) amancog@eafit.edu.co, mmarince@eafit.edu.co, lescob15@eafit.edu.co, aibeltrant@eafit.edu.co

${ }^{2}$ Ecopetrol S.A., Bogotá, Colombia. cjsanchez3@uh.edu.co

${ }^{3}$ Institute for Petrology and Geochemistry, ETH Zurich, Switzerland. albrecht.vonquadt@erdw.ethz.ch 


\section{Introduction}

Previous studies in the Caribbean province, located in the North Andean Block at northwestern South America, have been mainly focused on Late Cretaceous to Early Oligocene tectonostratigraphic sequences of the San Jacinto Fold Belt (SJFB), linking the Caribbean-South America plate boundary evolution to the Caribbean Plateau collision (e.g. Cardona et al., 2012; Mora et al., 2017b; Osorio-Granada et al., 2020) (Figure 1).

The Caribbean-South American convergent margin has shown different pulses of deformation since Late Cretaceous, period in which is suggested a subduction erosion after an accretionary event (Mora et al., 2017b,
2018). An Oligocene-Early Miocene stratigraphic section in the SJFB was studied, which is part of the Ciénaga de Oro Formation (COF) and represents the first episode of sedimentation above the Oligocene unconformity (Arminio et al., 2011).

Some uncertainties still prevail about the sediment source areas of Oligocene-Early Miocene rocks deposited along the SJFB area, and their relationship with the tectonic setting. This study strive to contribute to enhance the understanding of this complex issue by using a multi-tool approach throughout: 1) clastscounting in sandstones and conglomerates with mesh, 2) heavy minerals assemblages, 3) paleocurrents, and 4) $\mathrm{U}-\mathrm{Pb}$ detrital zircon ages.

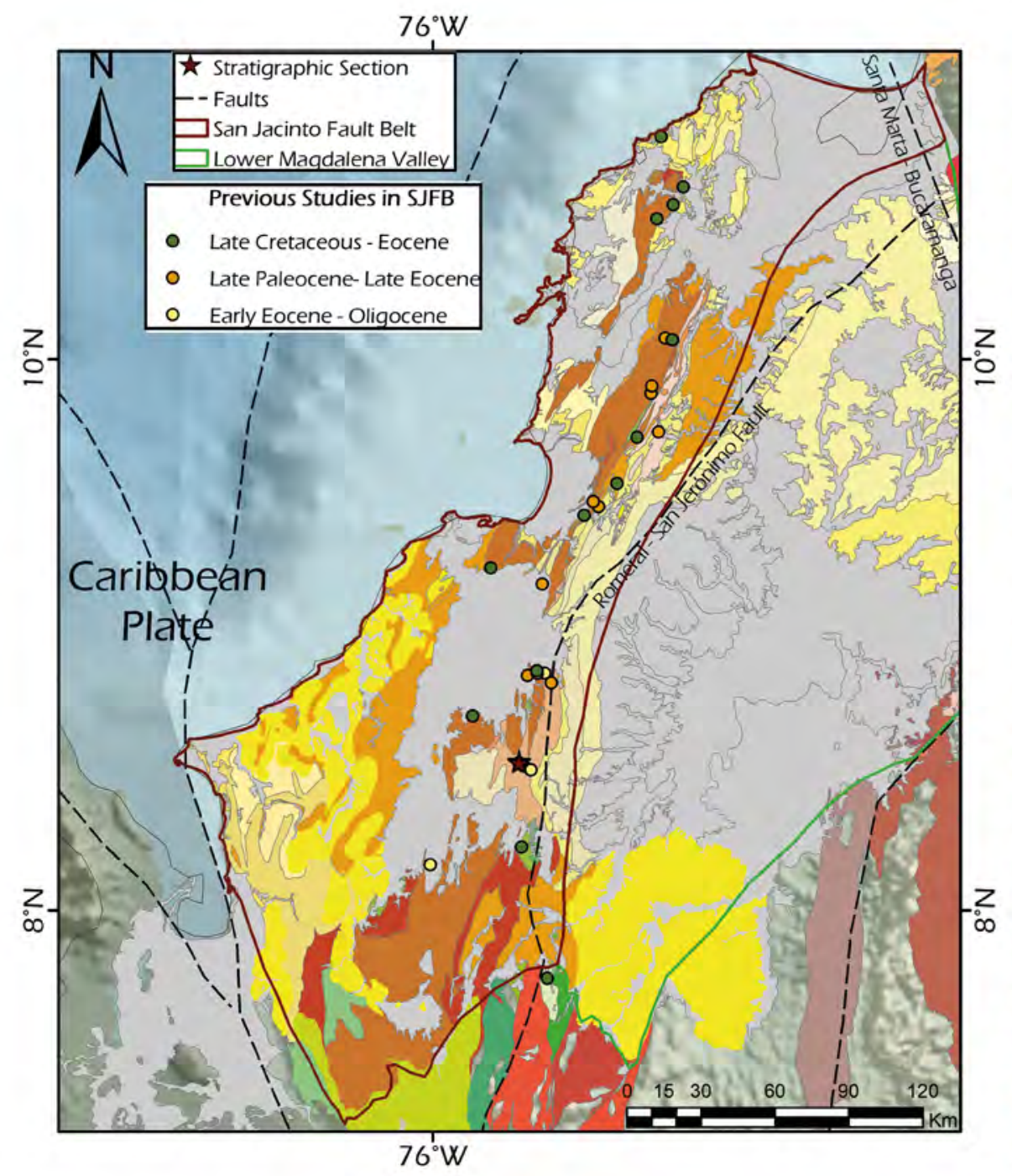

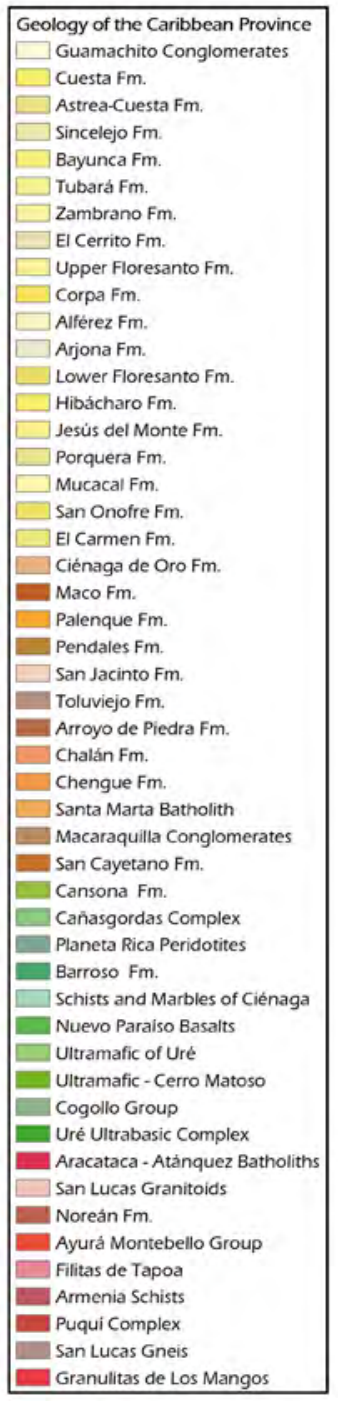

Figure 1. Geological map of the San Jacinto Fault Belt, the Sinú Fold Belt and Lower Magdalena Valley Basin. The location of previous studies on the Late Cretaceous - Eocene (Mora et al., 2017b), Late Paleocene - Late Eocene (Cardona et al., 2012), Early Eocene - Oligocene (Osorio-Granada et al., 2020) sediments and the stratigraphic section are also included. 


\section{Geological setting}

The San Jacinto Fold Belt (SJFB) is part of the Caribbean Terranes province (sensu Cediel et al., 2011) (Figure 2). The SJFB is limited by the Caribbean sea to the NW, the Lower Magdalena Valley Basin to the east, and the Western Cordillera to the south (Barrero et al., 2007; Cediel et al., 2011; Cardona et al., 2012). A dextral transpressive deformation, which generates a series of reverse west-vergent faults, and elongated folds that are oblique to the faults trend, has been proposed along the SJFB (Bermúdez et al., 2009; Cediel et al., 2011). The Sinú Fold Belt (SFB) is located to the west of the SJFB, and faulted against it along the Sinú fault (corresponding to the Sinú lineament at surface e.g. Aguilera, 2011). Gravimetric data in the SJFB reveal that it is a sedimentary basin formed by two depocenters in the northern and southern areas separated by a paleo-high (Alfaro and Holz, 2014a). The Central Continental Sub-Plate is located to the east of the Caribbean Terranes (Figure 2) and formed by a heterogeneous lithotectonic domain in which the Lower Magdalena Valley Basin (LMVB) is located (Aguilera, 2011; Alfaro and Holz, 2014a).

The LMVB has been described as a transtensionaltriangular shape basin (Reyes et al., 2004; Barrero et al., 2007) limited by the SJFB to the west, the metamorphic and igneous complex of Central Cordillera and the Serranía de San Lucas to the south and southeast, and the Bucaramanga-Santa Marta fault system to the east (Barrero et al., 2007; Arminio et al., 2011) (Figure 2). A basement high (Magangué-Cicuco High) divides the LMVB into El Plato and San Jorge sub-basins to the north and south, respectively, and controlled the sedimentation in these two depocenters from Eocene to Late Miocene (INGEOMINAS, 2003; Barrero et al., 2007; Silva-Arias et al., 2016). The LMVB has been classified as a Paleogene to Recent multiphase forearc and back-arc basin related to multiple tectonic phases (Arminio et al., 2011; Mora et al., 2018).

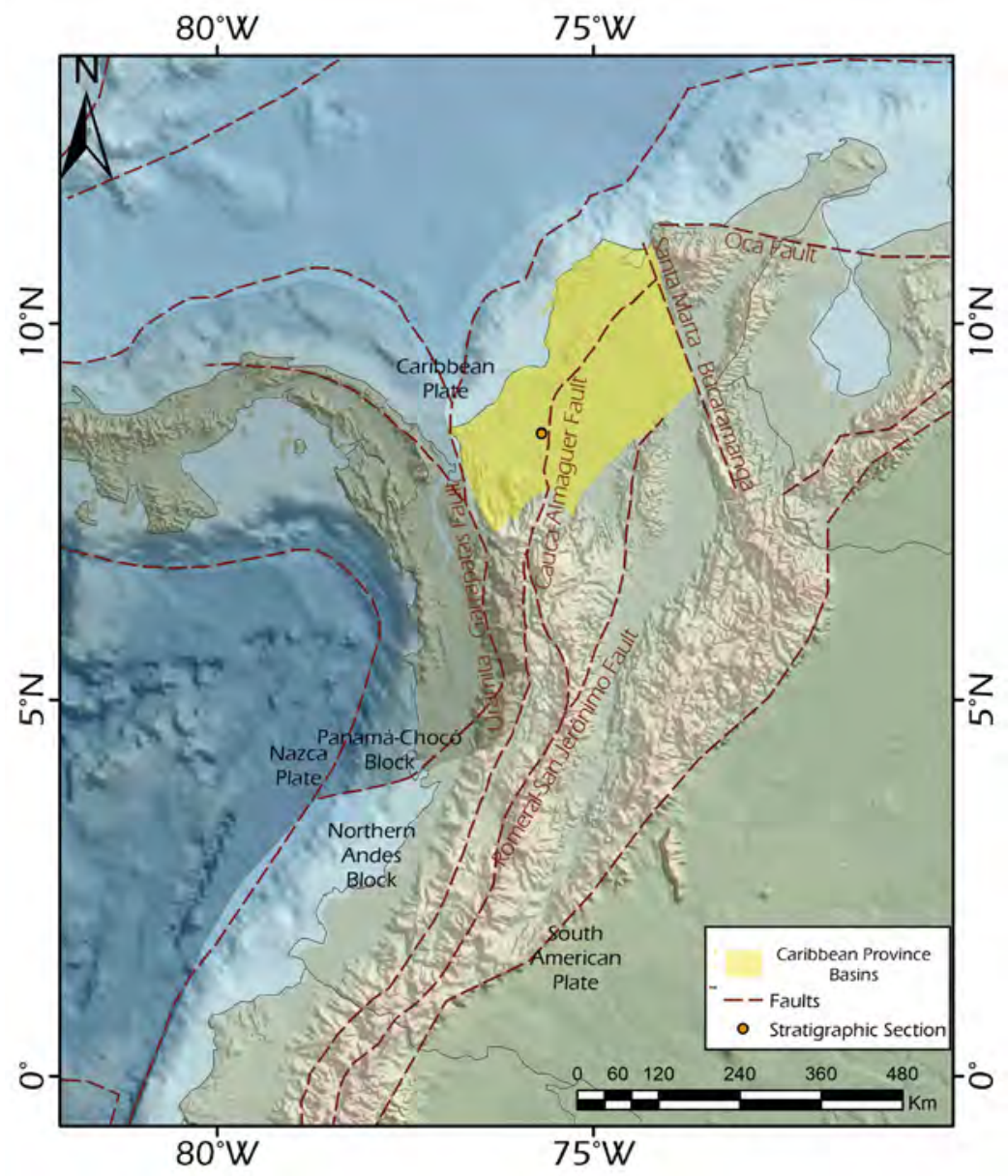

Figure 2. The North Andean Block with the Caribbean Province Basins (SJFB and LMVB), regional faults and the stratigraphic section location (modified after Cediel et al., 2003; Cortés and Angelier, 2005; Villagómez and Spikings, 2013; Caballero et al., 2016). 
The LMVB and the SJFB show correlative stratigraphy since the Oligocene (Figure 3), with shallower environments in the SJFB than in the San Jorge and Plato sub-basins. During the Paleocene and Eocene, the SJFB is interpreted as a more restricted basin, controlled by faults to the east, where the area of the LMVB could be emerged (Arminio et al., 2011; Rosero et al., 2014; Mora-Bohórquez, 2018).

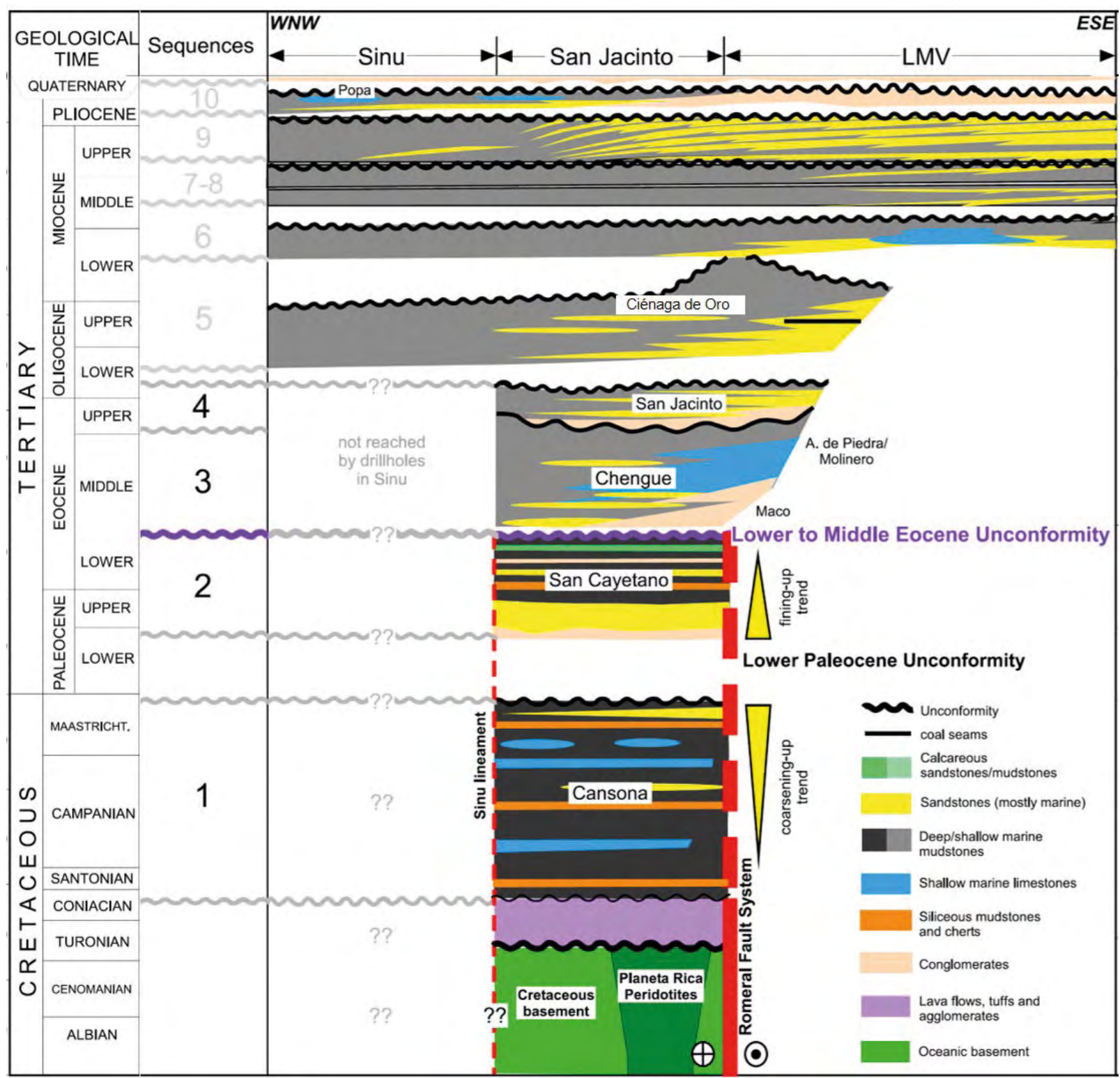

Figure 3. Chrono-lithostratigraphic distribution of Ciénaga de Oro Formation along San Jacinto Fold Belt (SJFB) and Lower Magdalena Valley Basin (LMVB). San Jacinto Formation, Chengue Formation, San Cayetano Formation, Cansona Formation and Cretaceous basement are also included (modified after Mora et al., 2017b).

\section{Stratigraphic section}

The Ciénaga de Oro Formation (COF), is part of the Oligocene-Early Miocene section of SJFB and the LMVB, between the older Eocene (?) Toluviejo and the younger mid-Miocene (?) Porquero formations. Arminio et al. (2011) proposed that Ciénaga de Oro Formation is an Oligocene transgressive succession that marks the first episode of sedimentation above the Oligocene unconformity. Furthermore, COF has been 
correlated chronostratigraphically with El Carmen and El Floral Formations (Barrero et al., 2007; Bermúdez et al., 2009; Rosero et al., 2014).

Thelithological, paleoenvironmental andpaleontological characteristics of the El Floral and the COF formations allow their integration as a single sedimentation event, from continental to transitional nature, which took place in deltaic to shallow marine environments (Guzmán et al., 2009; Bermúdez et al., 2009).

The COF has been divided into two members, differentiated by their grain size and corresponding to environments deposited at different depths (Dueñas and Duque-Caro, 1981; Guzmán et al., 2009; Bermúdez et al., 2009). The Lower Member of COF is characterized by Oligocene marine sediments with shales, fossiliferous sandstones, glauconitic sandstones and claystones, whereas the Upper Member includes Early Miocene deltaic transitional successions of conglomeratic fine sandstones (with igneous and sedimentary clasts), siltstones, coal, grey shales and calcareous-carbonaceous shales (e.g. Dueñas and Duque-Caro, 1981; Guzmán et al., 2009; Rosero et al., 2014; Alfaro and Holz, 2014b; Osorno and Rangel, 2015).

\section{Samples and methods}

The study area is a stratigraphic section of the COF along the Montería-Planeta Rica highway opened during the 2016 (Figure 4). The geographical coordinates for this section are $8^{\circ} 32^{\prime} 33.18^{\prime \prime} \mathrm{N}-75^{\circ} 41^{\prime} 14.15^{\prime \prime} \mathrm{W}$ to the base and $8^{\circ} 31^{\prime} 52.67^{\prime \prime} \mathrm{N}-75^{\circ} 40^{\prime} 32.64^{\prime \prime} \mathrm{W}$ to the top.

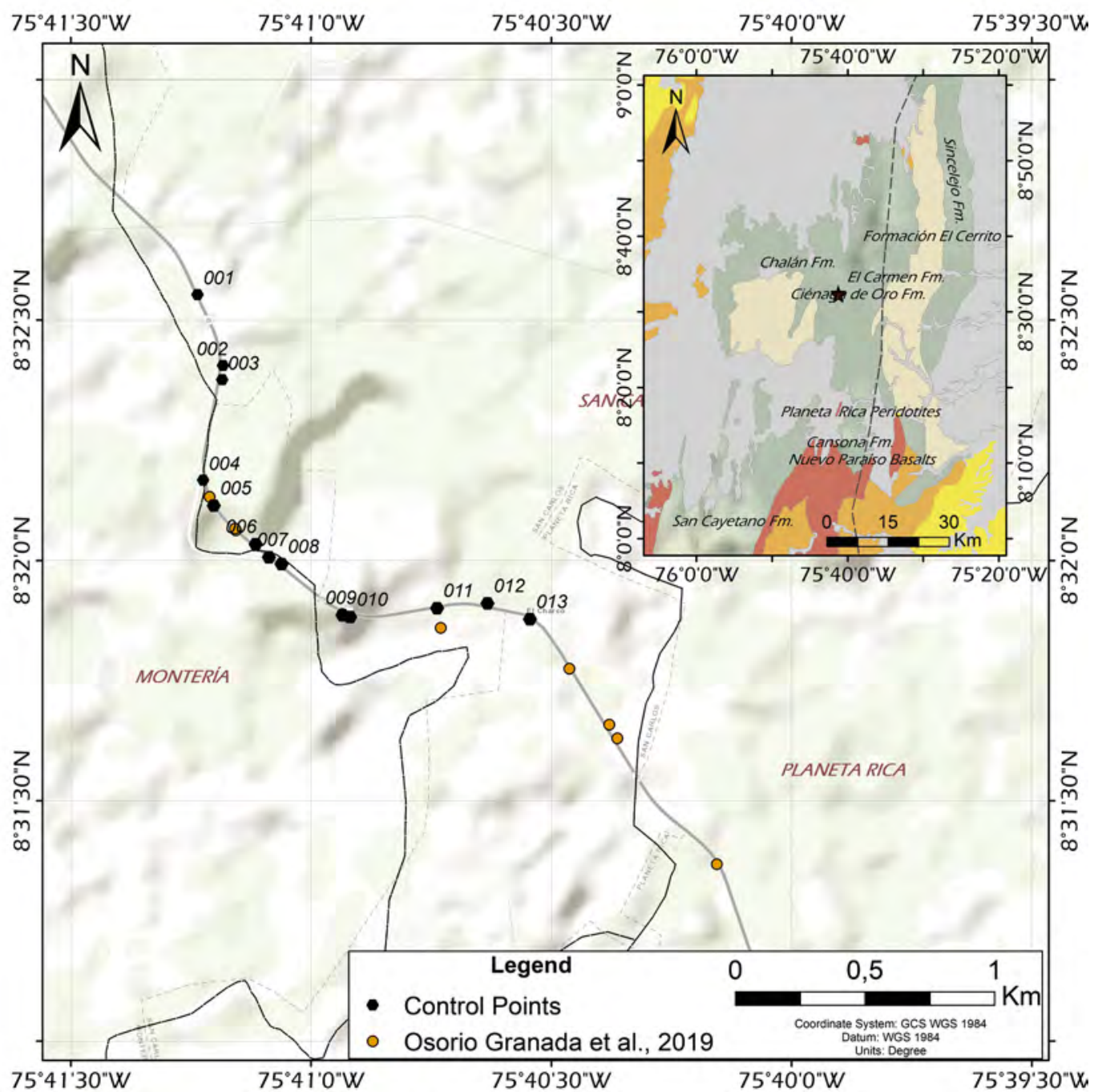

Figure 4. Data and samples collection control points for the stratigraphic section, geologic province of the Sinú-San Jacinto Basin and Lower Magdalena Valley Basin. 
Most of the road is closely normal to the structural trend, which allowed to measure, describe and collect samples from a stratigraphic section of $384 \mathrm{~m}$ for the COF with minor corrections (Figures 5 and 6).
To identify the sediment provenance of the COF, the following methods were applied: 1) counting of clasts with mesh, 2) a heavy mineral, 3) paleocurrents and 4) detrital zircons $\mathrm{U}-\mathrm{Pb}$ geochronology.
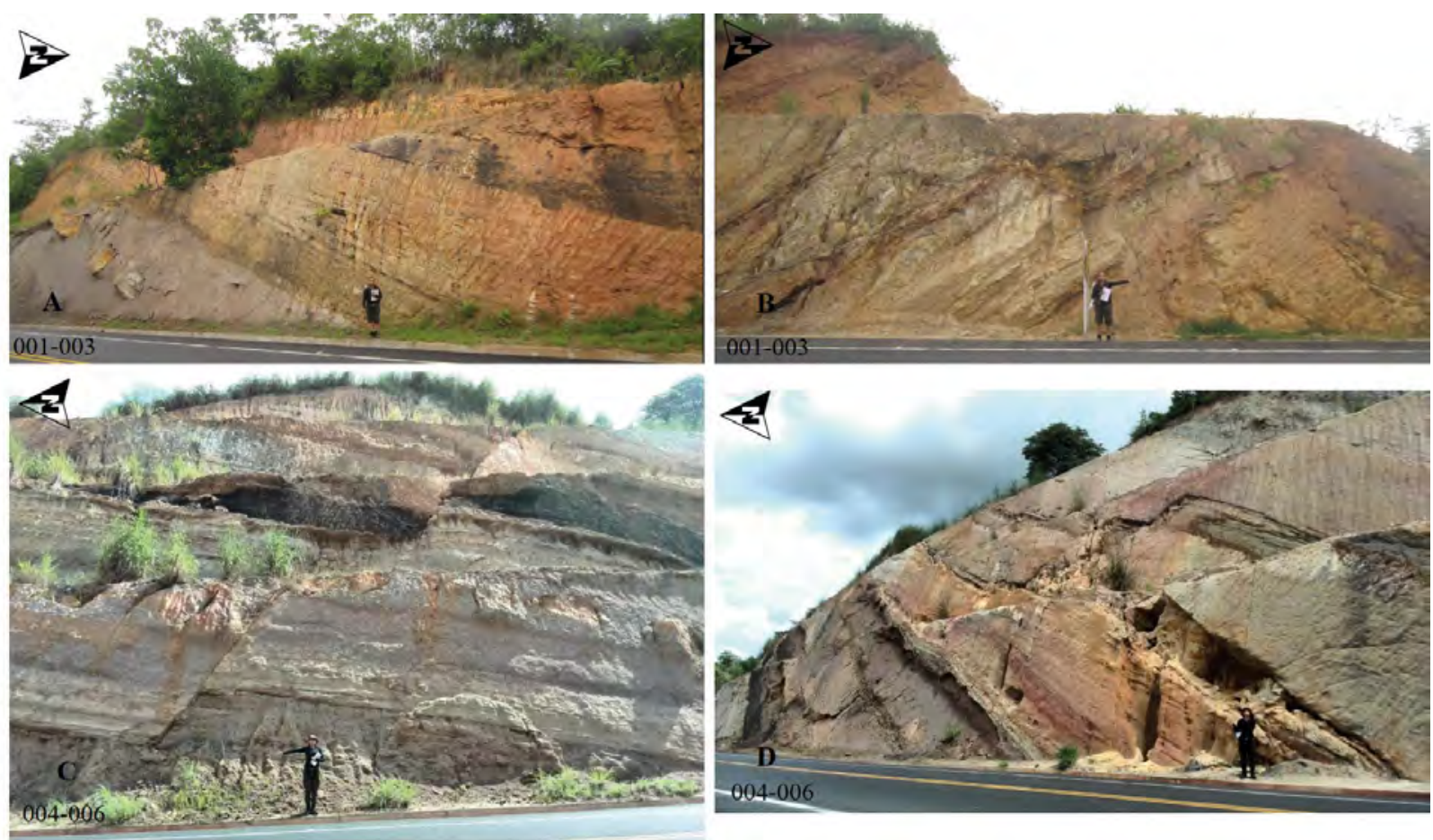

Figure 5. Photographic record of the study section at the data collection control points: A and B from 001 control point to 003 control point. $\mathbf{C}$ and $\mathbf{D}$ from 004 control point to 006 control point.

Along of the 384 m-thick studied stratigraphic section, 18 sedimentary cycles were interpreted, and different data were collected: I) fossiliferous content (mainly gastropods and bivalves), II) sedimentary structures, III) textural and compositional description, IV) clasts counting, and V) paleoflow measurements (Figure 6).

\section{Conglomeratic sandstone and sandy conglomerate counting with mesh}

Clast composition and its proportion from conglomeratic sandstones help elucidating sediment sources, as these particles tend to suffer less transport it is expected that their source would not have been far from the depocenter.

Direct measurements were made on the beds of conglomerate sandstones and sandy conglomerates at the stratigraphic section, simulating the count of framework grains made in a thin section at the microscopic level. This allows to identify and describe the characteristics of the clasts and their estimated amount in each bed (the Gazzi-Dickinson point counting method (Ingersoll et al., 1984)).

This statistical method was applied in conglomeratic sandstones and sandy conglomerates, where a 20x20 $\mathrm{cm}$ mesh with subdivisions of $1 \mathrm{~cm}$ was used. Counting of 400 clasts per bed was made for 10 beds along the section, for a total of 4000 counted clasts. Clasts of quartz, feldspar and lithic fragments were discriminated; sedimentological characteristics such as grain size, matrix composition, sorting and roundness of clasts, grain contacts were identified, and physical characteristics of clasts were described.

Subsequently, a statistical analysis of the data was carried out by determining the mineral percentages in each sample, which helped to identify their possible tectonic source by following tectoprovenance discrimination and compositional classification diagrams from Dickinson (1985) and Folk (1980), respectively. 


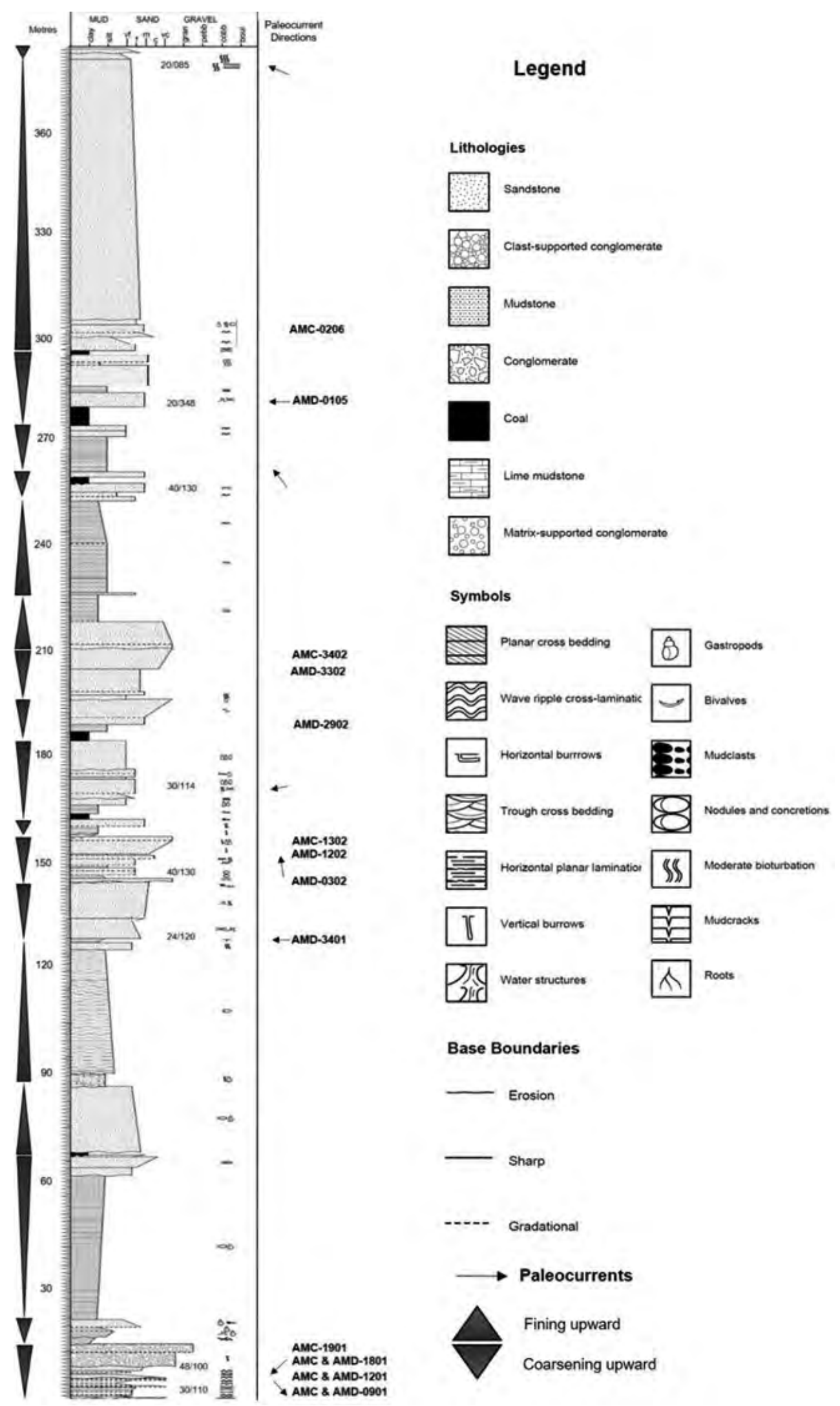

Figure 6. Integrated stratigraphic section with samples location, bed attitude and paleocurrent directions. Supplementary material. 


\section{Heavy minerals assemblages}

Nature of heavy minerals and their relative abundance in samples may be diagnostic of the sediment source rock composition, therefore their identification and statistic analysis are useful in sediment provenance analyses. Heavy minerals are characterized as accessory components of sedimentary rocks, which density is above $2.82 \mathrm{~g} / \mathrm{cm}^{3}$ (Mange and Maurer, 1992) and they facilitate the identification and discrimination of sediment source associations (Mange and Maurer, 1992; Mange and Wright, 2007).

Ten samples of conglomeratic sandstones and sandy conglomerates were taken from the same beds where clast counting was made. The heavy mineral preparation and optical analyses were carried out at EAFIT University.

The samples were disaggregated at the time of collection, and dry sieved with 18, 120 and 200 meshes whose apertures are $1 \mathrm{~mm}, 125 \mu \mathrm{m}$ and 75 $\mu \mathrm{m}$, respectively, separating very coarse, coarse to fine, and very fine sandstone grain sizes. Afterward, a pan was used to wash out the clay content from the 200 mesh, and then the sample was dried in an oven (Mange and Maurer, 1992; Mange and Wright, 2007). Heavy minerals content was concentrated with the pan to assemble minerals on a slide and slide cover with epoxy resins (Araldí LM-36A and LM-36B).

A line counting method of 300 grains was performed by using a reflected and transmitted light microscope. This study identified stable, ultra-stable and opaque mineral species of each heavy minerals assembly, for a total of 3000 counted grains. Subsequently, a statistical analysis of the data was carried out to determine the heavy minerals percentages, possible tectonic source, and natural association from each sample.

\section{Paleocurrent analysis}

Some sedimentary structures as planar and trough cross stratification, or some tool marks may record the flow direction during the sedimentation. Multiple paleocurrent analyses allow determining directions of flow and the vector of the sediment source (Tucker, 2003; Boggs, 2009).

Paleoflow structures - trough and planar cross bedding - were measured from 9 beds of sandstone beds along the stratigraphic section (DeCelles et al., 1983; Tucker, 2003). These data were corrected for the structural attitude of the beds by using the software Stereonet 9.8.3 (Allmendinger et al., 2013). Then, the results were plotted in rose diagrams to show their preferential directions. Different paleocurrent sets along the stratigraphic section were defined based on changes in direction patterns and were associated with depositional environments or/and paleoflow directions.

\section{$\mathrm{U}-\mathrm{Pb}$ geochronology in detrital zircon}

Detrital zircon geochronology resolves the crystallization age of the analyzed grains in order to associate them to their source rocks and tectonic setting (e.g. Cawood et al., 2012; Beltrán-Triviño et al., 2013; 2016). Detrital zircon separation followed standard procedures was performed at the Department of Earth Sciences at EAFIT University. Rock samples were crushed with a conventional jaw crusher, and the dense mineral fraction was separated from the 400-63 $\mu \mathrm{m}$ fraction by panning. Zircons were hand-picked from the heavy mineral concentrates in a random manner. After mounting in epoxy, zircon grains were polished, and carbon coated at ETH Zürich. Zircon cathodoluminescence (CL) was made using a Vega 3 (Tescan, Brno, Czech Republic) scanning electron microscope at the scientific center for optical and electron microscopy (ScopeM) at ETH Zürich.

Zircon $\mathrm{U}-\mathrm{Pb}$ geochronology was performed through laser ablation inductively coupled mass spectrometry (LA-ICP-MS) at the Institute of Geochemistry and Petrology at ETH Zurich. Laser ablation spots (19 microns) were selected in both cores and rims when it was possible. Analytical parameters and specification can be found in the Supplementary material.

\section{Results}

\section{Conglomeratic sandstone and sandy conglomerate counting}

Clast-counting was performed on seven locations of sandy conglomerates (three locations) and conglomeratic sandstones (four locations) beds along the stratigraphic section (Table 1, Figure 7A and 7B).

Counting from conglomeratic sandstones show mean gravel size between 2 and 4 millimeters, moderately to well-sorted, with subrounded to subangular clasts and reddish to white color. Quartz, feldspar, and lithic fragments (generally chert and a green rock) mainly have subangular to subrounded shape that suggest a 
moderate to low transport. The amount of quartz clasts increases from base to top, while the feldspar content tends to decrease. The content of lithic fragments remains relatively low. Furthermore, the roundness and sorting of the clasts tends to increase along the section, evidencing changes of coloration that could be associated with changes in the source's proximity.

Table 1. Results of conglomerate and sandstone counting analysis.

\begin{tabular}{ccccccc}
\hline Sample & $\mathbf{Q}$ & $\mathbf{F}$ & $\mathbf{F L}$ & $\mathbf{Q \%}$ & $\mathbf{F} \%$ & FL\% \\
\hline AMC-0901 & 132 & 220 & 48 & 33.00 & 55.00 & 12.00 \\
AMC-1201 & 102 & 246 & 52 & 25.50 & 61.50 & 13.00 \\
AMC-1801 & 148 & 202 & 50 & 37.00 & 50.50 & 12.50 \\
AMC-1901 & 116 & 236 & 48 & 29.00 & 59.00 & 12.00 \\
AMC-1302 & 121 & 233 & 46 & 30.25 & 58.25 & 11.50 \\
AMC-3402 & 152 & 196 & 52 & 38.00 & 49.00 & 13.00 \\
AMC-0206 & 144 & 206 & 50 & 36.00 & 51.50 & 12.50 \\
\hline
\end{tabular}

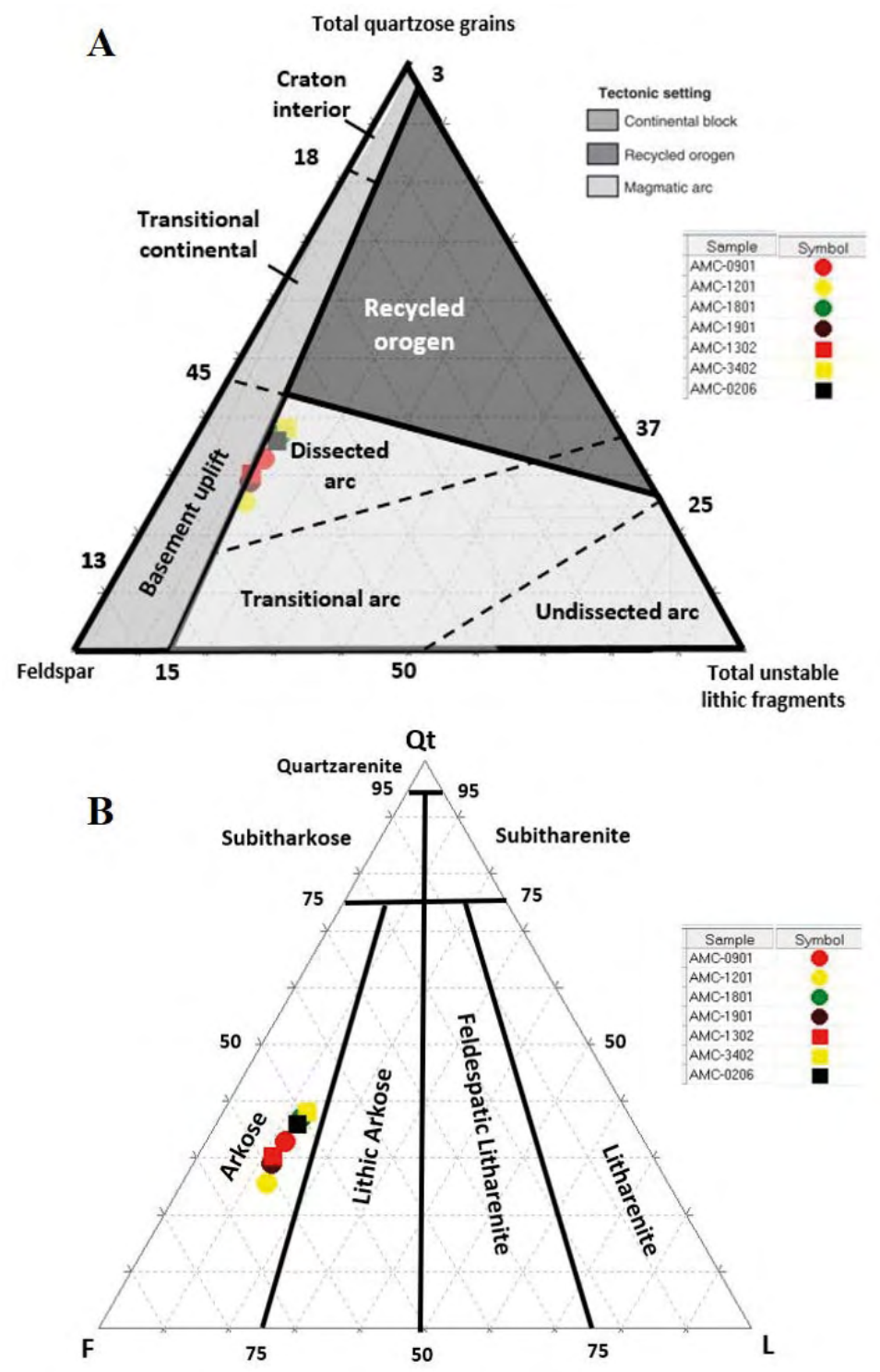

Figure 7. A. Sandstone provenance and tectonic setting for the stratigraphic section (modified from Dickinson (1985) in Boggs (2009)), and B. Sandstone classification (Folk, 1980). 
Sandy conglomerates showed an average grain size between 8 to 9 millimeters. Clasts features include moderate sorting, subrounding and a floating to tangential grain contacts that suggest low transport.

These rocks have reddish sandy matrix with calcareous content, with moderately sorted and subangular grains of quartz, feldspar, and lithic fragments (chert). The amount of quartz clast and feldspar varies along the section, and the content of lithic fragments remains low. Furthermore, the roundness and sorting of the clasts tends to increase from base to top of the section.

Tectonic provenance discrimination (Dickinson, 1985) and sandstone classification (Folk, 1980) diagrams show that beds of conglomeratic sandstone and sandy conglomerate are plotted in the dissected arc field and classified as arkoses (Figures 7A and 7B).

\section{Heavy minerals analysis}

The normalized percentage distribution of heavy minerals was obtained for ten samples that were also normalized without mica, to better differentiate the proportion of less frequent minerals (Figure 8A and 8B) (Van Loon and Pisarska-Jamrozy, 2017; Nyobe et al., 2018; Garzanti and Andò, 2019). In general, heavy minerals include ultrastable (zircon and tourmaline), diverse opaque minerals (mainly oxides), a significant amount of micas (muscovite > biotite), and several metastable minerals of igneous and metamorphic origin (Table 2). Prismatic crystals of zircon are more common that the amorphous ones in all the samples (Figure 9).

A
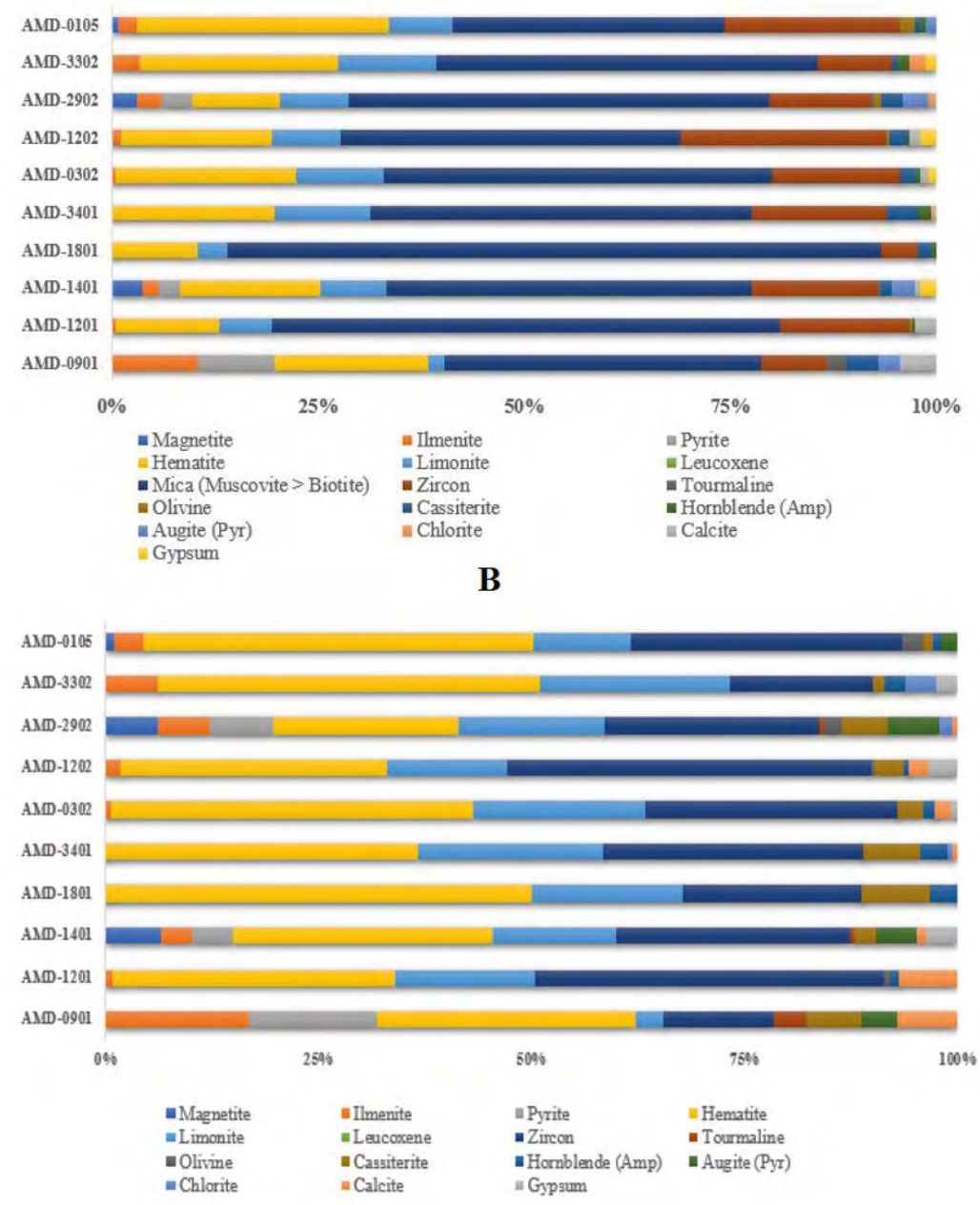

Figure 8. Heavy minerals concentration in the collected samples. A. Normalized distribution with micas. B. Normalized distribution without micas. 
Table 2. Heavy minerals percentages.

\begin{tabular}{|c|c|c|c|c|c|c|c|c|c|c|c|c|c|c|c|c|}
\hline & & & Op & $\begin{array}{l}\text { ques } \\
\text { o) }\end{array}$ & & & $\begin{array}{c}\text { Mica } \\
(\%)\end{array}$ & $\begin{array}{r}\text { Ultras } \\
(\%)\end{array}$ & able & & & & $\begin{array}{l}\text { tastal } \\
(\%)\end{array}$ & & & \\
\hline Sample & 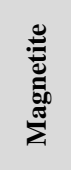 & 苞 & 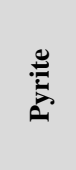 & 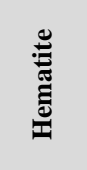 & 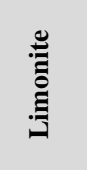 & 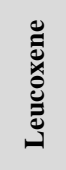 & 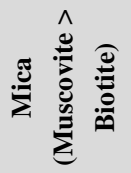 & 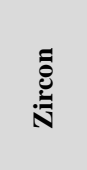 & 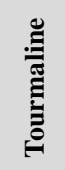 & 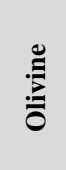 & 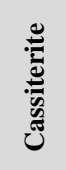 & 总 & 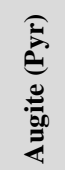 & & نั & 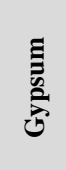 \\
\hline AMD-0901 & 0.00 & 10.33 & 9.33 & 18.67 & 2.00 & 0.00 & 38.33 & 8.00 & 2.33 & 0.00 & 4.00 & 0.00 & 2.67 & 0.00 & 4.33 & 0.00 \\
\hline AMD-1201 & 0.00 & 0.33 & 0.00 & 12.67 & 6.33 & 0.00 & 61.67 & 15.67 & 0.00 & 0.33 & 0.00 & 0.33 & 0.00 & 0.00 & 2.67 & 0.00 \\
\hline AMD-1401 & 3.67 & 2.00 & 2.67 & 17.00 & 8.00 & 0.00 & 44.33 & 15.33 & 0.33 & 0.00 & 1.33 & 0.00 & 2.67 & 0.00 & 0.67 & 2.00 \\
\hline AMD-1801 & 0.00 & 0.00 & 0.00 & 10.33 & 3.67 & 0.00 & 79.33 & 4.33 & 0.00 & 0.00 & 1.67 & 0.67 & 0.00 & 0.00 & 0.00 & 0.00 \\
\hline AMD-3401 & 0.00 & 0.00 & 0.00 & 19.67 & 11.67 & 0.00 & 46.33 & 16.33 & 0.00 & 0.00 & 3.67 & 1.67 & 0.00 & 0.33 & 0.33 & 0.00 \\
\hline AMD-0302 & 0.00 & 0.33 & 0.00 & 22.00 & 10.67 & 0.00 & 47.00 & 15.67 & 0.00 & 0.00 & 1.67 & 0.67 & 0.00 & 0.00 & 1.00 & 1.00 \\
\hline AMD-1202 & 0.00 & 1.00 & 0.00 & 18.33 & 8.33 & 0.00 & 41.33 & 25.00 & 0.00 & 0.33 & 2.00 & 0.33 & 0.00 & 0.00 & 1.33 & 2.00 \\
\hline AMD-2902 & 3.00 & 3.00 & 3.67 & 10.67 & 8.33 & 0.00 & 51.00 & 12.33 & 0.33 & 1.00 & 2.67 & 0.00 & 3.00 & 0.67 & 0.33 & 0.00 \\
\hline AMD-3302 & 0.00 & 3.33 & 0.00 & 24.00 & 12.00 & 0.00 & 46.33 & 9.00 & 0.00 & 0.00 & 0.67 & 1.33 & 0.00 & 2.00 & 0.00 & 1.33 \\
\hline AMD-0105 & 0.67 & 2.33 & 0.00 & 30.67 & 7.67 & 0.00 & 33.00 & 21.33 & 0.00 & 1.67 & 0.67 & 0.67 & 1.33 & 0.00 & 0.00 & 0.00 \\
\hline
\end{tabular}

The distribution of sulphide minerals tends to decrease from base to top, while the content of oxides, mainly hematite, increases with the ultrastable minerals content (e.g. zircon) along the section. Additionally, metastable minerals such as olivine, augite and chlorite increase their content from base to top, despite cassiterite, hornblende, calcite, and gypsum decrease. climatic conditions (e.g. Nichols, 2009; Lara et al., 2018) while the increase of ultrastable minerals with prismatic crystals such as zircon can indicate proximity of the source area. On the other hand, the increase of metastable minerals (such as olivine and augite) and the proportions of white mica could be related with the compositional change of the source area.

The decrease of sulphides and increase of oxides could indicate change in the depositional environment or

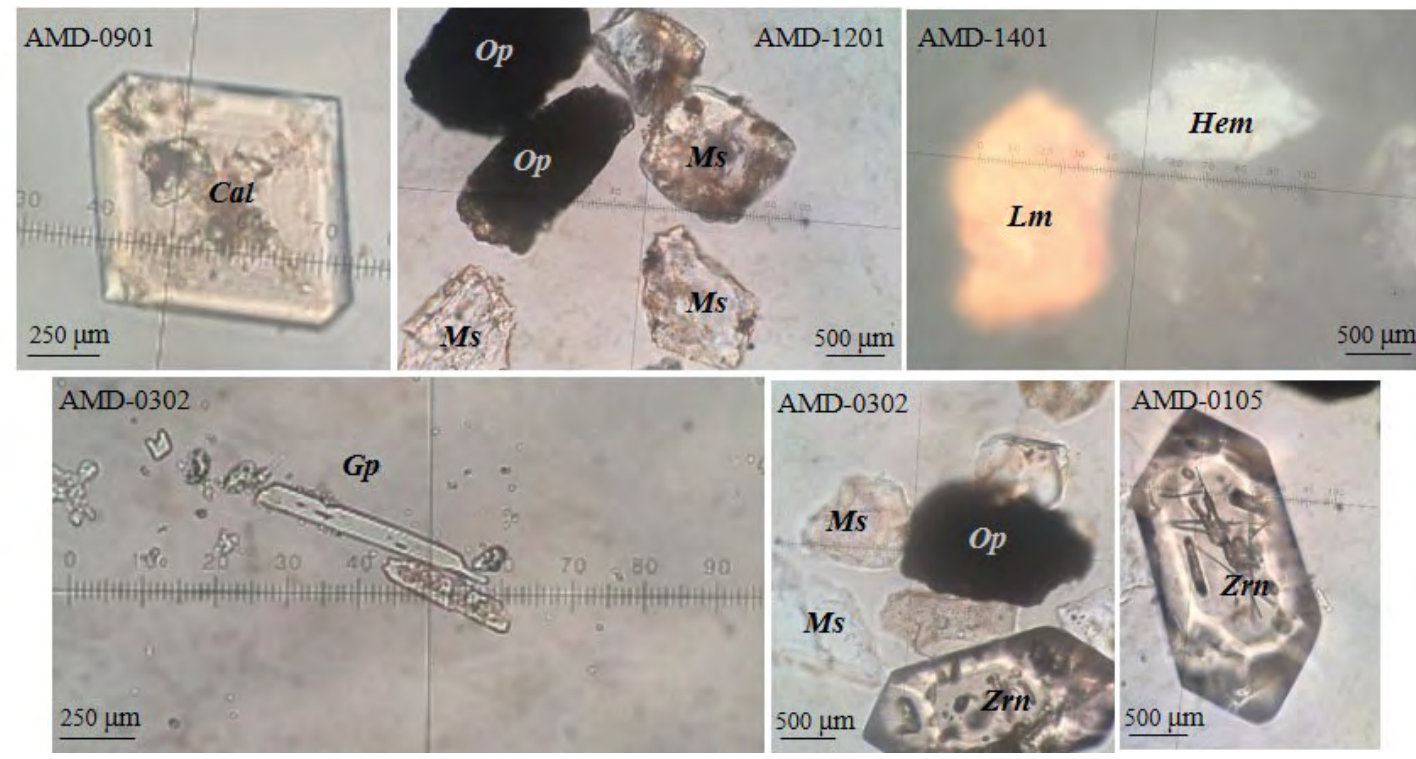

Figure 9. Ultrastable (AMD-0302, AMD-0105), metastable (AMD-0901, AMD-1201, AMD-0302) and opaque minerals (AMD1401). $\mathrm{Cal}=$ Calcite, $\mathrm{Gp}=$ Gypsum, Hem= Hematite, $\mathrm{Lm}=$ Limonite, Ms= Muscovite, Op= Opaque and Zrn= Zircon. 


\section{Paleocurrent analysis}

Results of paleocurrent analysis based on measurements of trough and planar cross bedding are shown in three different sets, identifying the mean flow vector and its dispersion along the stratigraphic section (Figure 10): Set 1 show means vectors and dispersion of the first meters in the section, from the base to $130 \mathrm{~m}$; Set 2 from 130 to $280 \mathrm{~m}$, Set 3 from 295 to $380 \mathrm{~m}$ (Table 3A and 3B Supplementary material). Each set is differentiated by their dominant direction quadrants in the rose diagrams and their stratigraphic position along the section.

The first set of paleocurrents (S1) shows a unimodal pattern directed to the SE in the first structure measure; a bimodal oblique pattern directed to the NEE-ESE; a polymodal pattern directed to SE-SW-WNW, and a unimodal pattern directed to the $\mathrm{W}$ in the last measure from this segment (Figure 10). This set consists of 23 measurements (17 trough cross bedding and 6 planar cross bedding).

The second set of paleocurrents (S2) shows unimodal patterns directed to the $\mathrm{N}, \mathrm{SWW}$ and NW, consisting of 18 measurements (7 trough cross bedding and 11 planar cross bedding). The third set of paleocurrents (S3) has 8 measurements of planar cross bedding, and shows unimodal patterns directed to the $\mathrm{W}$ and WNW.

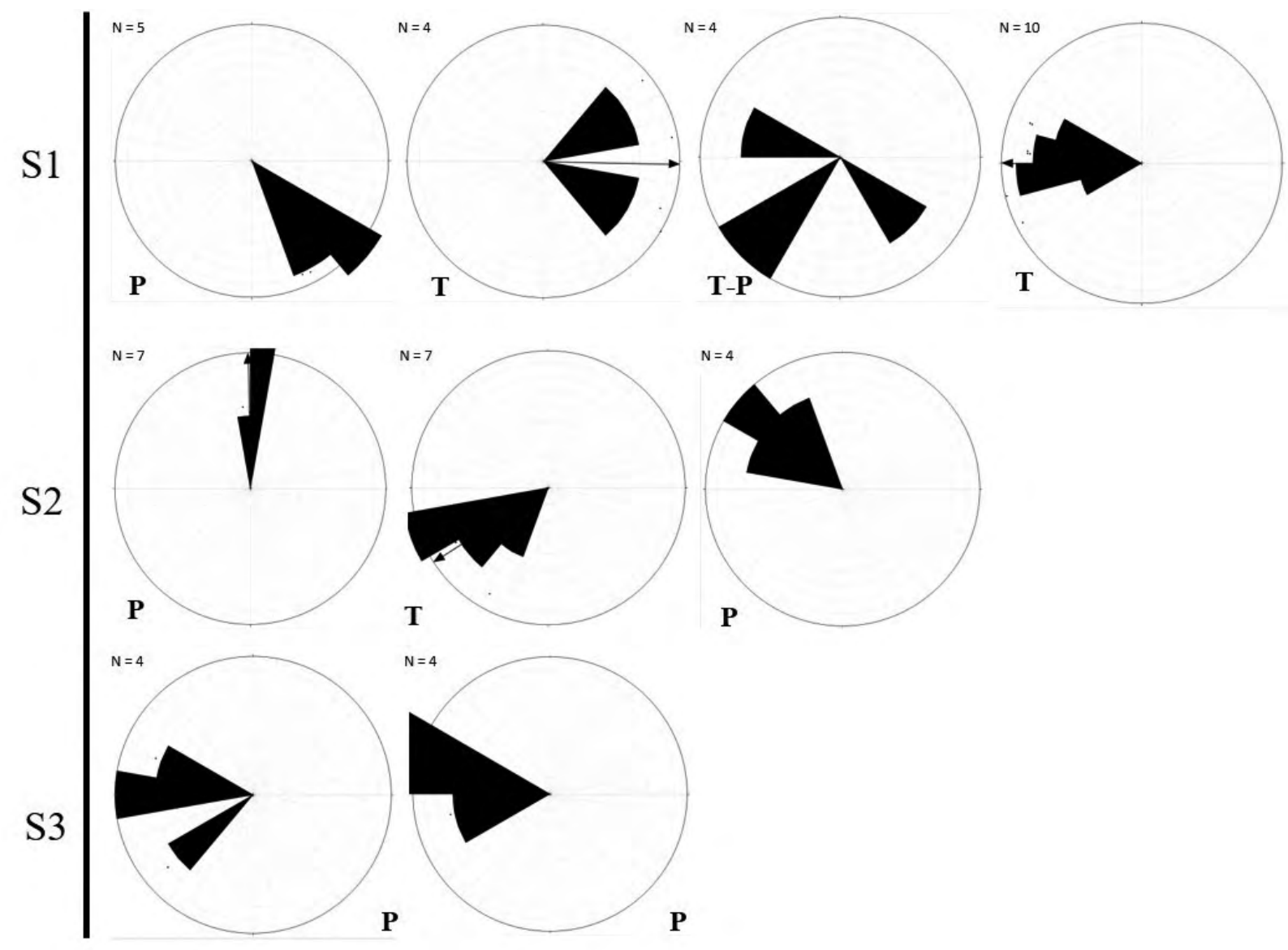

Figure 10. Paleocurrents patterns along the section. $\mathrm{P}=$ Planar cross bedding, $\mathrm{T}=$ Trough Cross bedding, $\mathrm{S} 1=\mathrm{Set} 1, \mathrm{~S} 2=$ Set 2 , S3= Set 3 .

\section{$\mathrm{U}-\mathrm{Pb}$ detrital zircon geochronology}

Three (3) medium-grained sandstone samples (AM0901, AM1201 and AM2902) (Figure 6) were chosen for U-Pb detrital zircon geochronology. Onehundred and ninety-seven (197) detrital zircons were dated for the three samples. In general, the sandstones show two dominant groups of ages, Late Cretaceous (ca. $75 \mathrm{Ma}$ ) and Early Triassic (ca. $240 \mathrm{Ma}$ ) (Figure 11). Furthermore, a population of Permian ages can be identified (250-300 Ma). The lowermost sandstones (AM0901 and AM1201) also display minor populations at Late Jurassic (ca. 150-160 Ma) and 
Early Carboniferous (ca. $340 \mathrm{Ma}$ ). In the lowermost sandstone (AM0901) is remarkable the presence of some zircons dated at 100 and 140 Ma (Cretaceous). The maximum depositional ages for the lowermost part
(AM0901) of the section is $75.2 \pm 0.9 \mathrm{Ma}$, for the middle (AM1201) is 68.9 $\pm 0.6 \mathrm{Ma}$ and for the uppermost part (AM2902) of the section is $74.5 \pm 0.7 \mathrm{Ma}$.
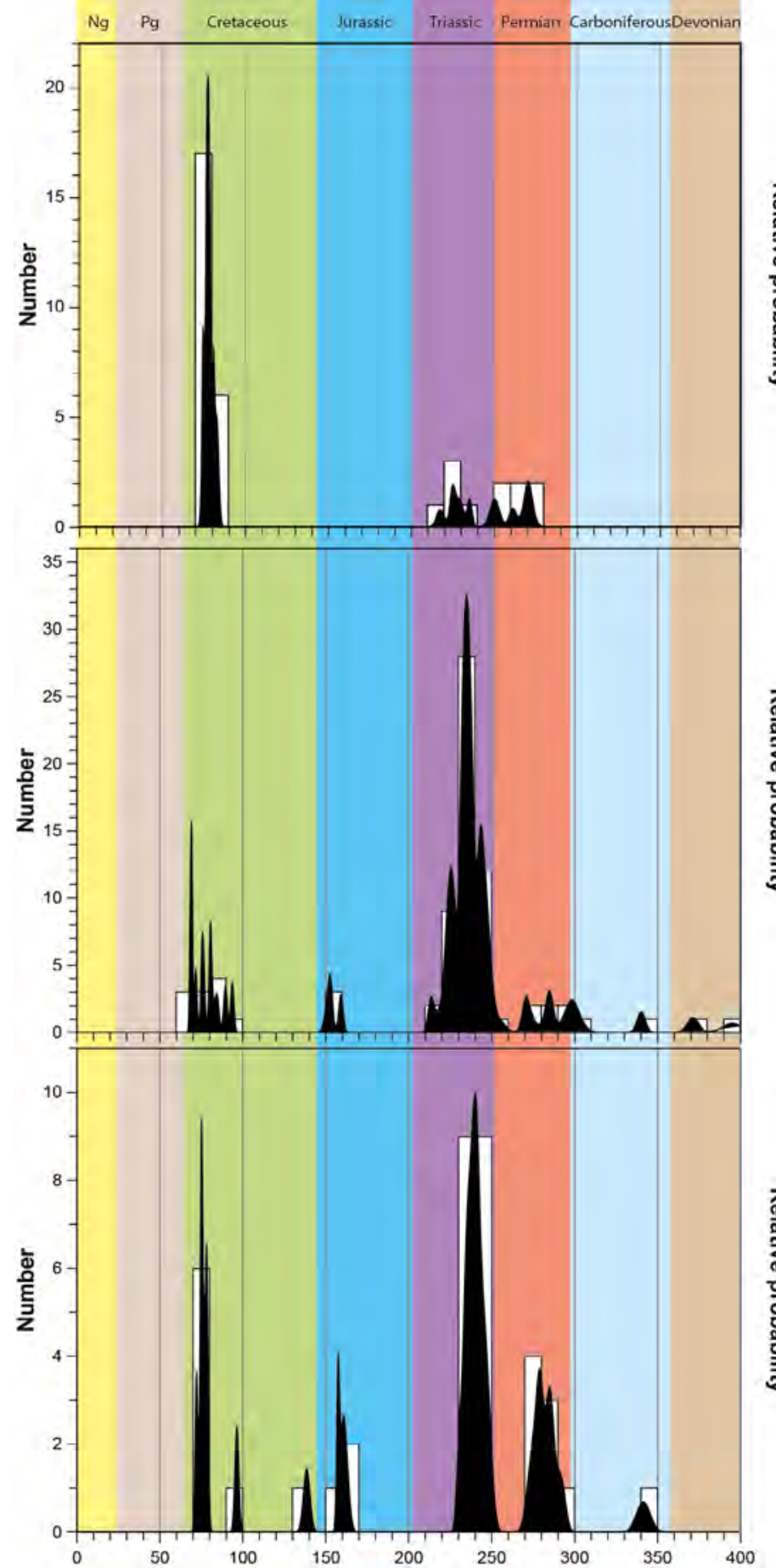

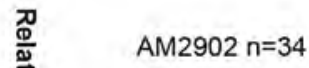

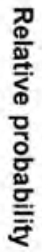

AM1201 $n=76$

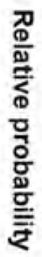

AM0901 $n=38$

Figure 11. Age frequency histograms of U-Pb detrital zircons geochronology. Note peaks of Late Cretaceous (75 Ma) and Early Triassic (240 Ma) age. 


\section{Discussion}

Provenance interpretation, heavy minerals assemblages, and $\mathrm{U}-\mathrm{Pb}$ detrital zircon geochronology

Provenance discrimination diagrams from conglomeratic sandstone and sandy conglomerate samples show dissected arc affinity because of a mixture of volcanic-derived rock fragments, plagioclase, K-feldspar and quartz from igneous bodies (andesitic to basaltic) (Boggs, 2009) (Figure 7). It indicates a moderate influence of climate and minimal effects of transport. A petrographic analysis from Osorio-Granada et al. (2020) for the Ciénaga de Oro Formation (COF) rocks, stratigraphically higher than our study section, reported quartzarenites and sublitharenites, while a restricted proportion comprises subarkoses.

According to Dickinson (1985) and Boggs (2009), magmatic arcs are belts of positive relief composed of volcanic and plutonic igneous rocks produced by subduction along arc-trench systems, and dissected arcs expose deep seated plutonic rocks with higher proportion of plutonic detritus. Derived sandstones and conglomerates from dissected arcs show less volcano lithic fragments than those from undissected arcs. Additionally, arkoses are related to deposition under a semi-arid climate, fluvial systems environment and granitic-gneisses sources (Folk, 1980; Tucker, 2003; Worden and Burley, 2003; Boggs, 2009).

The general high content of heavy minerals along the section, such as muscovite (48.9\%), hornblende (0.6\%), cassiterite $(1.8 \%)$, zircon (14.3\%) and tourmaline $(0.3 \%)$ suggest an acid igneous to granite pegmatite composition as the principal source rock (Figure 12). Also, the high proportion of white mica suggests metapelitic source rocks. On the other hand, the minor heavy minerals contents of magnetite $(0.7 \%)$, limonite (7.9\%), augite $(1.0 \%)$ and olivine $(0.3 \%)$, suggest a basic igneous secondary source (Figure 12).

The subangular to subrounded shape of lithic fragments (mostly chert than igneous and metamorphic), feldspar and quartz, the conglomeratic and sandy-conglomeratic textures, and the preservation of metastable material (hornblende, biotite and cassiterite) suggest that the sediment source could have been proximal from the deposition place.

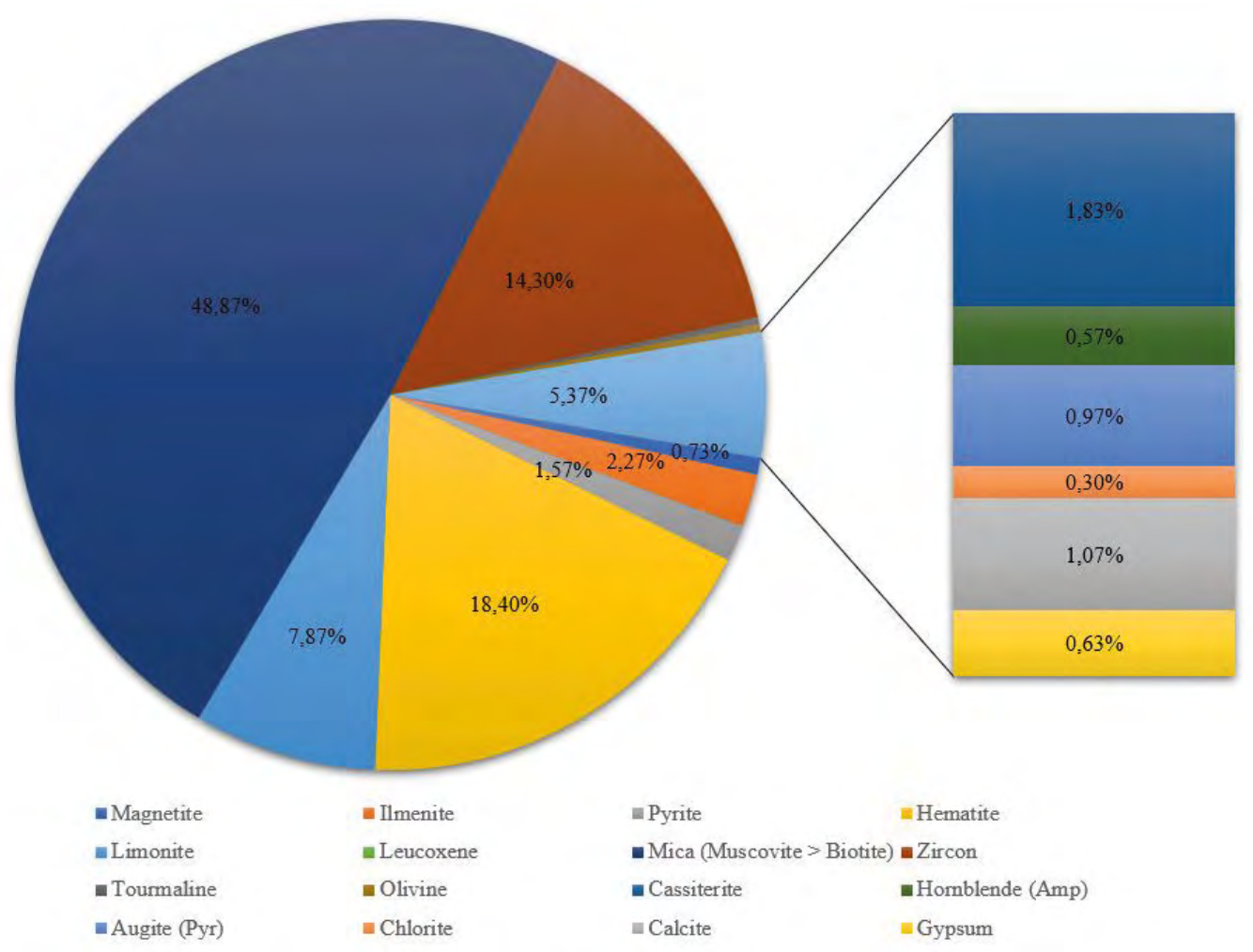

Figure 12. Total heavy minerals percentage in the stratigraphic section. 
$\mathrm{U}-\mathrm{Pb}$ detrital zircon geochronology ages linked with paleocurrents directions allow to propose some specific sources areas based on the geochronological database available for the Central and Western Cordilleras and/ or the lack of sources with younger ages. The most plausible source areas are: Triassic (250-228 Ma) plutons from the Central Cordillera (Pueblito Diorite and Amagá Stock; Vinasco et al., 2006; Leal-Mejia, 2011), the Late Cretaceous Antioqueño Batholith (94 Ma - 56 Ma; Correa et al., 2006; Ordóñez et al., 2007; Restrepo-Moreno et al., 2009; Leal-Mejia, 2011; Villagómez et al., 2011). Potential Late Cretaceous plutonic source rocks from the Western Cordillera are the Sabanalarga Batholith-Santa Fe de Antioquia and the Altamira and Buriticá plutons (100 Ma-88 Ma; Ordóñez et al., 2007; Weber et al., 2015; ZapataVillada et al., 2017).
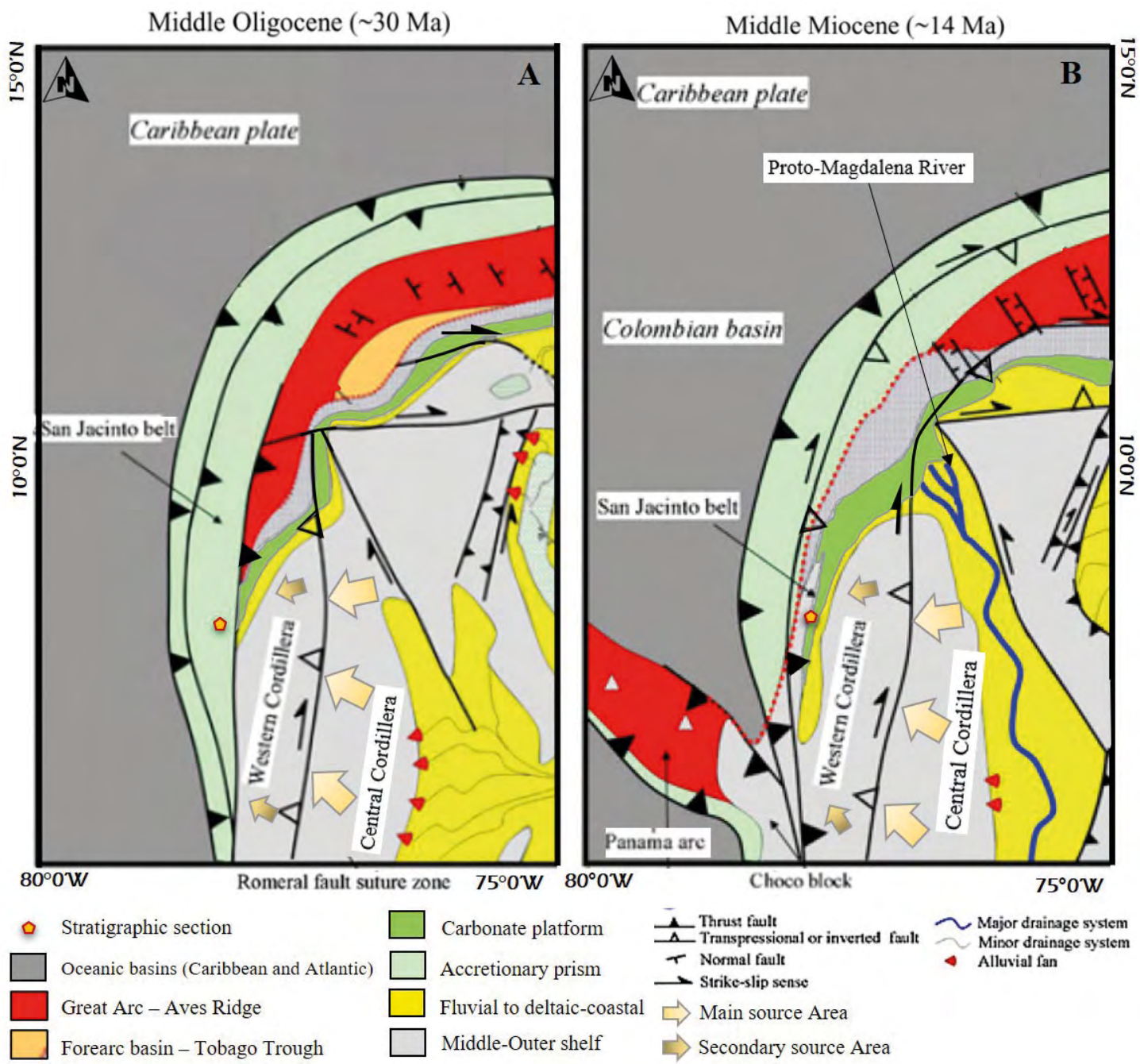

\section{Provenance significance in sedimentary environments}

According to the paleogeographic maps of Villamil (1999) and Escalona and Mann (2011), the COF was located in a shore-deltaic environment and fluvial to deltaic environment during the Oligocene and Miocene, respectively (Figure 13). Detailed macroscopic and microscopic lithological descriptions, facies analysis, and a paleoenvironmental reconstruction (ca. 130 m-thick section, Figure 4) was analyzed by CastilloGuerra and Soto-López (2017). They proposed deltaic to shore/foreshore transitional environments, suggesting an auto-cyclic deltaic system rather than an eustatic main control during the deposition.

Figure 13. Regional paleogeographic maps for Middle Oligocene and Middle Miocene, stratigraphic section location and potentials sources areas (modified after Escalona and Mann, 2011). 
Set 1 (S1) of paleocurrents may be related to shore, foreshore and delta plain transition environments (Castillo-Guerra and Soto-López, 2017), which might suggest that the high dispersion in the paleocurrent directions is related to the migration of delta channels (Tucker, 2003). The unimodal patterns of set 2 (S2) and set 3 (S3) may be interpreted as the transitional flow direction of deltaic to fluvial channels, which dispersion reflects river sinuosity. The different directions of unimodal patterns of the second and third paleocurrent set (S2 and S3) suggest a lobate to elongate delta system with a reduced wave and tidal effect, and the dominance of transitional river processes (Tucker, 2003; Boggs, 2009). According to these results, the main sediment transport direction is from east-southeast to west-northwest, which means that the sediment source was located to the eastsoutheast from the deposition area.

Most of the U-Pb detrital zircons ages are Late Cretaceous (aprox. $75 \mathrm{Ma}$ ) and Early Triassic (aprox. $250 \mathrm{Ma}$ ) suggesting predominant sediment source rocks of these ages, such sediments were deposited during the Oligocene (34-24 Ma) as proposed by Dueñas and Duque-Caro (1981), Jaramillo et al., (2011) and Osorio-Granada et al., (2020). The study from Osorio-Granada et al., (2020) indicates that sediments of the COF were deposited in tropical coastal and shallow marine environments, where the sediments were transported by short rivers from the crystalline massifs of the Lower Magdalena Valley and the northern Central Cordillera basements, while distal transport of sediments may have occurred along longer rivers, which brought sediments from southern regions located between the Central and Western Cordilleras.

\section{Tectonostratigraphic events}

The interaction between the Caribbean and South American plate has been explained by two tectonic models: I) the allochthonous model that suggests a pacific origin of the Caribbean plate by Late Cretaceous and the later north-northeast migration (Pindell et al., 2005; Kerr and Tarney, 2005; Escalona and Mann, 2011) and II) the autochthonous model, which proposes a Caribbean plate origin from the separation among North and South American plates since a Triassic to Jurassic intracontinental rifting (James, 2009b), indicating a polyphase rifting in San Jacinto Basin (e.g. Alfaro and Holz, 2014b).
Consequently, the Sinú-San Jacinto Fold Belts (SSJFB) has been interpreted in different ways: I) as an accretionary arc system deformed by the Caribbean and South America convergence, which contrasts with the constitution of the Andean Cordillera (Flinch, 2003; Vallejo et al., 2006; Bustamante et al., 2011; Cardona et al., 2012); II) as an accretionary prism with Cenozoic low-angle thrust imbricates, linked with the interaction between the oceanic Caribbean plate and the South America plate (Kellogg et al., 2005; Vinnels et al., 2010; Arminio et al., 2011; Cediel et al., 2011; Bernal-Olaya et al., 2015; Mora et al., 2017a, 2017b), and III) as an accommodation space related to an intracontinental rifting result of the Caribbean plate formation (James, 2009a, 2009b; Alfaro and Holz, 2014b). The results of this study show evidence of lithological and mineral assemblage associated with an igneous acid (granitic to pegmatitic composition) sediment source rocks from a dissected arc, and in minor proportions, an igneous basic source rocks. It concurs with a collisional interaction between Caribbean and South America, generating a magmatic arc and subsequent erosional process.

In the study area - the SJFB - at the western of the Romeral Fault System, there is still debate about the nature of the basement; according to Mantilla-Pimiento (2007) and Bermúdez et al. (2009), the area has a preUpper Cretaceous igneous-metamorphic continental basement. However, an oceanic Upper Cretaceous basement has been proposed by some other authors (Dueñas and Duque-Caro, 1981; Flinch, 2003; Vallejo et al., 2006; Guzmán et al., 2009; Cardona et al., 2012). For the LMVB, Permo-Triassic migmatites, granulites, amphibolites and biotitic gneisses have been reported as the eastern basement of the basin (Flinch, 2003; Mora et al., 2017a). Furthermore, the Upper Cretaceous oceanic crust found near Sinú-San Jacinto Fold Belt (SSJFB) are related with accretional process result of the oblique collision of Caribbean plate and northern South America plate, and both basins (the LMVB and SJFB) basement have continental or transitional crust affinity (e.g. Montes et al., 2010; Mora et al., 2017a).

Recent provenance studies of Paleogene conglomerates in the San Jacinto Basin have suggested sedimentary sources related to Late Cretaceous Intra-Oceanic arc mixed with Permo-Triassic Continental basement (Cardona et al., 2012), as found in the Western Cordillera, Santa Marta and Guajira regions. The analyzed geochemical data of magmatic clast, from the same study, show affinity of an intraoceanic 
calc-alkaline magmatic arc with a high proportion of igneous-metamorphic lithics, indicating a volcanoplutonic of intermediate to mafic character for the main source area. Also, it suggests that the SSJFB are related to a forearc type or a transcurrent accreted terrane, which were the result of a Late Cretaceous arccontinent collision ( 75-73 Ma). Mantilla-Pimiento et al. (2009), based on a 3D density model, proposed an offscraping mechanism for emplacement of ultramafic and mafic rocks in the San Jacinto Belt over continental rocks of a tectonic wedge during subduction of the Caribbean plate. Both models link the SSJFB to a transient arc-continental collision.

Arminio et al. (2011) and Mora et al. (2017a, 2017b) suggest a Central Cordillera source for SJFB Basin sediments - Late Cretaceous volcano-plutonic rocks of the northern part of Central Cordillera, which occupied the area now covered by LMVB (Aguilera, 2011) - . In addition, Aguilera (2011) proposes that the provenance for Paleogene sediments in the LMVB from volcanic rocks to the south, related to the Central Cordillera, based on geochemical data that link emplacement and metamorphism ages around $61 \mathrm{Ma}$ with Central Cordillera Orogenesis (Andean Orogenia). According to Mora et al. (2017b) the detrital zircon $\mathrm{U}-\mathrm{Pb}$ geochronology suggests Upper Cretaceous and Permo-Triassic basement block sources for the Upper Paleocene to the Lower Oligocene sediments of the SJFB.

The results of paleocurrent and petrographic analyses suggest an E-SE location of the source area, and two main sediment sources: an acid igneous rock as principal one, and a basic igneous rock as a secondary source (Figures 7 and 10); hence that supports the idea of the Central Cordillera as the main potential source area, being located to the east and southeast of the COF during the Oligocene and Early-Miocene (Figure 13). Furthermore, Late Cretaceous granitoids in the LMVB (Mora et al., 2017a) may have been sediment source for the COF in the SJFB, as these plutonic rocks might have been exposed by late Oligocene-Early Miocene. Restricted mafic and ultramafic Cretaceous igneous bodies (e.g. Planeta Rica Peridotite, Montelibano Peridotite, Nuevo Paraiso basalts) in the SJFB could supply a minor proportion of sediments during the deposition of the COF (e.g. Bernal-Olaya et al., 2015; Silva-Arias et al., 2016; Mora et al., 2017a; MoraBohórquez, 2018).

\section{Conclusions}

Provenance analysis of sedimentary rocks undergird the understanding of basement configuration and paleoenvironmental evolution for the Late OligoceneEarly Miocene of northwestern Colombia and tectonic events related to their depositional process. These findings agree better with the para-autochthonous model for Caribbean and South America plates interaction in which the presence of Late Cretaceous magmatic arcs is suggested, and accretional prism model for the Sinú-San Jacinto Fold Belts basin.

The petrographic and paleocurrent analyses suggest granitic to pegmatitic rocks of the Central Cordillera as the main source area, and possibly other Late Cretaceous granitoids bodies in the LMVB (Mora et al., 2017a).

Detrital zircon geochronology analysis identifies four age populations: (I) Permian, (II) Early Triassic, (III) Late Jurassic and (IV) Late Cretaceous, with maximum depositional ages of $75.2 \pm 0.9 \mathrm{Ma}$ in the lower part of the section, $68.9 \pm 0.6 \mathrm{Ma}$ in the middle and $74.5 \pm 0.7$ Ma for the upper part of the section. A south-north oriented fluvial system carried sediments from late Cretaceous plutons like Antioqueño Batholith and mafic/ultramafic rocks to Sinú, San Jacinto and Lower Magdalena Valley basins, and depict the basement of the Central and Western Cordilleras.

\section{Acknowledgments}

The authors of this study thank the Thermochronology laboratory of EAFIT University that belongs to the Red Nacional de Laboratorios de Geociencias (RNLG) for its support during the elaboration of heavy mineral analysis. The authors also thank the geologist Daniel Monterrosa for his accompaniment during the field work, the professor Andrés Leonardo Cárdenas for his advice during the approach of this work, the Research Seedbed Regional geology and geochemistry and the Research Seedbed of Tectonostratigraphy at EAFIT University which belongs to the Geología Ambiental e Ingeniería Sísmica Research Group. 


\section{References}

Aguilera, R. (2011). Petroleum geology of Colombia. Sinú and San Jacinto Basins. Vol. 12. Universidad Eafit - ANH.

Alfaro, E.; Holz, M. (2014a). Review of the chronostratigraphic charts in the Sinú-San Jacinto basin based on new seismic stratigraphic interpretations. Journal of South American Earth Sciences, 56, 139-169. https://doi.org/10.1016/j. jsames.2014.09.004

Alfaro, E.; Holz, M. (2014b). Stratigraphic relationships between the Colombian, Sinú Offshore and SinúSan Jacinto basins based on seismic stratigraphy. Brazilian Journal of Geology, 44(4), 607-625.

Allmendinger, R.W.; Cardozo, N.C.; Fisher, D. (2013). Structural geology algorithms: vectors \& tensors. Cambrigde, England: Cambridge University Press.

Arminio, J.F.; Yoris, F.; Porras, L.; García, E.; Diluca, M. (2011). Petroleum geology of Colombia. Lower Magdalena Basin. Vol. 10. Universidad Eafit - ANH.

Barrero, D.; Pardo, A.; Vargas, C.A.; Martínez, J.F. (2007). Colombian sedimentary basins: Nomenclature, boundaries and petroleum geology, a new proposal. ANH and B\&M Exploration Ltda.

Bermúdez, H.D.; Alvarán, M.; Grajales, J.A.; Restrepo, L.; Rosero, J.S.; Guzmán, C.; Ruiz, E.; Navarrete, R.; Jaramillo, C.; Osorno, F. (2009). Estratigrafía y evolución geológica de la secuencia sedimentaria del Cinturón Plegado de San Jacinto. XII Congreso Colombiano de Geología. Paipa, Colombia.

Beltrán-Triviño, A.; Winkler, W.; von Quadt, A. (2013). Tracing Alpine sediment sources through laser ablation U-Pb dating and Hf-isotopes of detrital zircons. Sedimentology, 60(1), 197-224. https://doi.org/10.1111/sed.12006

Beltrán-Triviño, A.; Winkler,W.; von Quadt, A.; Gallhofer, D. (2016). Triassic magmatism on the transition from Variscan to Alpine cycles: evidence from $\mathrm{U}-\mathrm{Pb}, \mathrm{Hf}$, and geochemistry of detrital minerals. Swiss Journal of Geosciences,
109(3), 309-328. https://doi.org/10.1007/s00015016-0234-3

Bernal-Olaya, R.; Mann, P.; Escalona, A. (2015). Cenozoic tectonostratigraphic evolution of the Lower Magdalena Basin, Colombia: An example of an Under-to Overfilled Forearc Basin. In: C. Bartolini, P. Mann (eds.). Petroleum geology and potential of the Colombian Caribbean Margin (pp. 345-398). The American Association of Petroleum Geologists.

Boggs, S.J. (2009). Petrology of sedimentary rocks. 2nd edition. Cambridge University Press.

Bustamante, A.; Juliani, C.; Hall, C.M.; Essene, E.J. (2011). ${ }^{40} \mathrm{Ar} /{ }^{39} \mathrm{Ar}$ ages from blueschists of the Jambaló region, Central Cordillera of Colombia: implications on the styles of accretion in the Northern Andes. Geologica Acta, 9(3-4), 351362. http://dx.doi.org/10.1344/105.000001697

Caballero, J.H.; Rendón, A.; Gallego, J.J.; Uasapud, N.V. (2016). Inter-Andean Cauca River Canyon. In: M. Hermelin (ed.). Landscapes and Landforms of Colombia (pp. 155-166). Springer, Cham. https://doi.org/10.1007/978-3-319-11800-0_13

Cardona, A.; Montes, C.; Ayala, C.; Bustamante, C.; Hoyos, N.; Montenegro, O.; Ojecla, C.; Niño, H.; Ramirez, V.; Valencia, V.; Rincón, D.; Vervoort, J.; Zapata, S. (2012). From arc-continent collision to continuous convergence, clues from Paleogene conglomerates along the southern CaribbeanSouth America plate boundary. Tectonophysics, 580, 58-87. https://doi.org/10.1016/j. tecto.2012.08.039

Castillo-Guerra, S.; Soto-López, L. (2017). Reconstrucción paleoambiental de la Formación El Floral - Ciénaga de Oro a partir de una sección estratigráfica entre los municipios de Montería y Planeta Rica. Tesis, Universidad Eafit, Colombia.

Cawood, P.A.; Hawkesworth, C.J.; Dhuime, B. (2012). Detrital zircon record and tectonic setting. Geology, 40(10), 875-878. https://doi. org/10.1130/G32945.1

Cediel, F.; Shaw, R.P.; Cáceres, C. (2003). Tectonic assembly of the Northern Andean Block. In: C. Bartolini; R. Buffler; J. Blickwede (eds.). 
The Circum-Gulf of México and Caribbean: Hydrocarbon Habitats, Basin Formation and Plate Tectonics (pp. 815-848). vol. 79. AAPG.

Cediel, F.; Leal-Mejía, H.; Shaw, R.P.; Melgarejo, J.C.; Restrepo-Pace, P.A. (2011). Petroleum geology of Colombia. Regional Geology of Colombia. Vol. 1. Universidad Eafit - ANH.

Correa, A.M.; Pimentel, M.; Restrepo, J.J.; Nilson, A.; Ordoñez, O.; Martens, U.; Laux, J.E.; Junges, S. (2006). U-Pb zircon ages and Nd-Sr isotopes of the Altavista Stock and the San Diego Gabbro new insights on Cretaceous arc magmatism in the Colombian Andes. V Simposio Sudamericano de Geología Isotópica, Punta del Este, Uruguay.

Cortés, M.; Angelier, J. (2005). Current states of stress in the northern Andes as indicated by focal mechanisms of earthquakes. Tectonophysics, 403(1-4), 29-58. https://doi.org/10.1016/j. tecto.2005.03.020

DeCelles, P.G.; Langford, R.P.; Schwartz, R.K. (1983). Two new methods of paleocurrent determination from trough cross-stratification. Journal of Sedimentary Research, 53(2), 629-642. https:// doi.org/10.1306/212F824C-2B24-11D78648000102C1865D

Dickinson, W.R. (1985). Interpreting provenance relations from detrital modes of sandstones. In: G.G. Zuffa (ed.). Provenance of Arenites (pp. 333-361). Springer Netherlands. https://doi. org/10.1007/978-94-017-2809-6_15

Dueñas, H.; Duque-Caro, H. (1981). Geología del cuadrángulo F-8, Planeta Rica. Boletín Geológico, 24(1), 1-35.

Escalona, A.; Mann, P. (2011). Tectonics, basin subsidence mechanisms, and paleogeography of the Caribbean-South American plate boundary zone. Marine and Petroleum Geology, 28(1), 8-39. https://doi.org/10.1016/j.marpetgeo.2010.01.016

Flinch, J.F. (2003). Structural evolution of the SinuLower Magdalena Area (Northern Colombia). In: C. Bartolini, R. Buffler, J. Blickwede (eds.). The Circum-Gulf of Mexico and the Caribbean: Hydrocarbon habitats, Basin Formation, and Plate Tectonics (pp. 776-796). Vol. 79. AAPG.
Folk, R.L. (1980). Petrology of sedimentary rocks. Hemphill Publishing Company.

Garzanti, E.; Andò, S. (2019). Heavy minerals for junior woodchucks. Minerals, 9(3). https://doi. org/10.3390/min9030148

Guzmán, W.; García, A.M.; Ramiréz, C. (2009). Estudio petrográfico y diagenético de la secuencia cenozoica del Cinturón Plegado de San Jacinto y su aplicación en la determinación de la calidad de reservorios. XII Congreso Colombiano de Geología. Paipa, Colombia.

INGEOMINAS. (2003). Geología de los Cinturones Sinú - San Jacinto-Memoria Explicativa. INGEOMINAS.

Ingersoll, R.V.; Bullard, T.F.; Ford, R.L.; Grimm, J.P.; Pickle, J.D.; Sares, S.W. (1984). The effect of grain size on detrital modes: A test of the GazziDickinson point countaing method. Journal of Sedimentology Research, 54(1), 103-116. https://doi.org/10.1306/212F83B9-2B24-11D78648000102C1865D

James, K.H. (2009a). Evolution of Middle America and the in situ Caribbean Plate model. Geological Society, London, Special Publications, 328(1), 127-138. https://doi.org/10.1144/SP328.4

James, K.H. (2009b). In situ origin of the Caribbean: discussion of data. Geological Society, London, Special Publications, 328(1), 77-125. https://doi. org/10.1144/SP328.3

Jaramillo, C.A.; Machado, A.; D’Apolito, C.; Paez, M. (2011). Micropaleontología y Palinología de la Formación Cansona. Cretácico Superior, Cuenca Sinu-San Jacinto, Colombia. Ecopetrol.

Kellogg, J.; Toto, E.; Ceron, J. (2005). Structure and Tectonics of the Sinu-San Jacinto Accretionary Prism in Northern Colombia. $X$ Congreso Colombiano de Geología, Bogotá, Colombia.

Kerr, A.C.; Tarney, J. (2005). Tectonic evolution of the Caribbean and northwestern South America: The case for accretion of two late cretaceous oceanic plateaus. Geology, 33(4), 269-272. https://doi. org/10.1130/G21109.1 
Lara, M.; Salazar-Franco, A.M.; Silva-Tamayo, J.C. (2018). Provenance of the Cenozoic siliciclastic intramontane Amagá Formation: Implications for the early Miocene collision between Central and South America. Sedimentary Geology, 373, 147-162. https://doi.org/10.1016/j. sedgeo.2018.06.003

Leal-Mejia, I. (2011). Phanerozoic gold metallogeny in the colombian Andes: A tectono-magmatic approach. Ph.D. Thesis. Universitat de Barcelona, Barcelona, Spain.

Mange, M.A.; Maurer, H.F.W. (1992). Heavy minerals in colour. 1st edit. London: Chapman \& Hall.

Mange, M.A.; Wright, D.T. (2007). Heavy minerals in use. 1st edit. Amsterdam: Elsevier.

Mantilla-Pimiento, A.M. (2007). Crustal structure of the Southwestern Colombian Caribbean margin: Geological interpretation of geophysical data. Ph.D. Thesis, Friedrich Schiller University Jena, Germany.

Mantilla-Pimiento, A.M.; Jentzsch, G.; Kley, J.; Alfonso-Pava, C. (2009). Configuration of the Colombian Caribbean Margin: Constraints from 2D seismic reflection data and potential fields interpretation. In: S. Lallemand; F. Funiciello (eds.). Subduction Zone Geodynamics (pp. 247272). Springer-Verlag Berlin Heidelberg.

Montes, C.; Guzman, G.; Bayona, G.; Cardona, A.; Valencia, V.; Jaramillo, C. (2010). Clockwise rotation of the Santa Marta massif and simultaneous Paleogene to Neogene deformation of the PlatoSan Jorge and Cesar-Ranchería basins. Journal of South American Earth Sciences, 29(4), 832-848. https://doi.org/10.1016/j.jsames.2009.07.010

Mora, J.A.; Ibánez-Mejia, M.; Oncken, O.; de Freitas, M.; Vélez, V.; Mesa, A.; Serna, L. (2017a). Structure and age of the Lower Magdalena Valley basin basement, northern Colombia: New reflection-seismic and $\mathrm{U} \mathrm{Pb}-\mathrm{Hf}$ insights into the termination of the central andes against the Caribbean basin. Journal of South American Earth Sciences, 74, 1-26. https://doi.org/10.1016/j. jsames.2017.01.001
Mora, J.A.; Oncken, O.; Le Breton, E.; IbánezMejia, M.; Faccenna, C.; Veloza, G.; Vélez, V.; de Freitas, M.; Mesa, A. (2017b). Linking Late Cretaceous to Eocene Tectonostratigraphy of the San Jacinto fold belt of NW Colombia with Caribbean Plateau collision and flat subduction. Tectonics, 36(11), 2599-2629. https://doi. org/10.1002/2017TC004612

Mora, J.A.; Oncken, O.; Le Breton, E.; Mora, A.; Veloza, G.; Vélez, V.; de Freitas, M. (2018). Controls on forearc basin formation and evolution: Insights from Oligocene to Recent tectonostratigraphy of the Lower Magdalena Valley basin of northwest Colombia. Marine and Petroleum Geology, 97, 288-310. https://doi.org/10.1016/j. marpetgeo.2018.06.032

Mora-Bohórquez, J.A. (2018). Upper Cretaceous to recent plate tectonics, basin formation and tectono-stratigraphy of the Lower Magdalena Valley and San Jacinto fold belt of Northwestern Colombia: implications for hydrocarbon systems. Ph.D. Thesis, Free University of Berlin, Germany.

Nichols, G. (2009). Sedimentology and Stratigraphy. (2nd ed.). United Kingdom: Wiley-Blackwell.

Nyobe, J.M.; Sababa, E.; Bayiga, E.C.; Ndjigui, P.D. (2018). Mineralogical and geochemical features of alluvial sediments from the Lobo watershed (Southern Cameroon): Implications for rutile exploration. Comptes Rendus Geoscience, 350(3), 119-129. https://doi.org/10.1016/j. crte.2017.08.003

Ordóñez, O.; Pimentel, M.; Laux, J.H. (2007). Edades U-Pb del batolito Antioqueño. Boletín de Ciencias de la Tierra, 22, 129-130.

Osorio-Granada, E.; Pardo-Trujillo, A.; RestrepoMoreno, S.A.; Gallego, F.; Muñoz, J.; Plata, A.; Trejos-Tamayo, F.; Vallejo, F.; BarbosaEspitia, A.; Cardona-Sánches, F.J.; Foster, D.A.; Kamenov, G. (2020). Provenance of EoceneOligocene sediments in the San Jacinto Fold Belt: Paleogeographic and geodynamic implications for the northern Andes and the southern Caribbean. Geosphere, 16(1), 210-228. https:// doi.org/10.1130/GES02059.1 
Osorno, J.; Rangel, A. (2015). Geochemical assessment and petroleum systems in the Sinú-San Jacinto Basin, northwestern Colombia. Marine and Petroleum Geology, 65, 217-231. https://doi. org/10.1016/j.marpetgeo.2015.03.022

Pindell, J.; Kennan, L.; Maresch, W.V.; Stanek, K.P.; Draper, G.; Higgs, R. (2005). Plate-kinematics and crustal dynamics of circum-Caribbean arccontinent interactions: Tectonic controls on basin development in Proto-Caribbean margins. In: H.G. Lallemant, V.G. Sisson (eds.). CaribbeanSouth American plate iteractions, Venezuela (pp. 7-52). vol. 394. Geological Society of America. https://doi.org/10.1130/0-8137-2394-9.7

Restrepo-Moreno, S.A.; Foster, D.; Stockli, D.F.; Parra-Sánchez, L.N. (2009). Long-term erosion and exhumation of the "Altiplano Antioqueño", northern Andes (Colombia) from apatite (UTh)/He thermochronology. Earth and Planetary Science Letters, 278(1-2), 1-12. https://doi. org/10.1016/j.epsl.2008.09.037

Reyes, H.A.; Montenegro, B.M.; Gómez, P.D. (2004). Tectonoestratigrafía y evolución geológica del Valle Inferior del Magdalena. Boletín de Geología, 26(42), 19-38.

Rosero, S.; Silva, J.C.; Sial, A.N.; Borrero, C.; Pardo, A. (2014). Quimioestratigrafía de isótopos de estroncio de algunas sucesiones del eocenomioceno del Cinturón de San Jacinto y el Valle Inferior del Magdalena. Boletín de Geología, 36(1), 15-27.

Silva-Arias, A.; Páez-Acuña, L.A.; Rincón-Martínez, D.; Tamara-Guevara, J.A.; Gomez-Guitierrez, P.D.; López-Ramos, E.; Restrepo-Acevedo, S.M.; Mantilla-Figueroa, L.C.; Valencia, V. (2016). Basement characteristics in the Lower Magdalena Valley and the Sinú and San Jacinto Fold Belts: Evidence of a Late Cretaceous Magmatic Arc at the South of the Colombian Caribbean. CT\&F Ciencia, Tecnología y Futuro, 6(4), 5-36.

Tucker, M.E. (2003). Sedimentary rocks in the field. 3rd edit. England: John Wiley \& Sons Ltd.

Vallejo, C.; Spikings, R.A.; Luzieux, L.; Winkler, W.; Chew, D.; Page, L. (2006). The early interaction between the Caribbean Plateau and the NW South American Plate. Terra Nova, 18(4), 264-269. https://doi.org/10.1111/j.13653121.2006.00688.x

Van Loon, A.J.; Pisarska-Jamrozy, M. (2017). Changes in the heavy-mineral spectra on their way from various sources to joint sinks: A case study of Pleistocene Sandurs and an ice-marginal valley in Northwest Poland. In: R. Mazumder (ed.). Sediment Provenance: Influences on Compositional Change from Source to Sink (pp. 49-62). Chapter 4. Elsevier Inc.

Villagómez, D.; Spikings, R. (2013). Thermochronology and tectonics of the Central and Western Cordilleras of Colombia: Early Cretaceous - Tertiary evolution of the Northern Andes. Lithos, 160-161, 228-249. https://doi. org/10.1016/j.lithos.2012.12.008

Villagómez, D.; Spikings, R.; Magna, T.; Kammer, A.; Winkler, W.; Beltrán, A. (2011). Geochronology, geochemistry and tectonic evolution of the Western and Central Cordilleras of Colombia. Lithos, 125(3-4), 875-896. https://doi.org/10.1016/j. lithos.2011.05.003

Villamil, T. (1999). Campanian-Miocene tectonostratigraphy, depocenter evolution and basin development of Colombia and western Venezuela. Palaeogeography, Palaeoclimatology, Palaeoecology, 153(1-4), 239-275. https://doi. org/10.1016/S0031-0182(99)00075-9

Vinasco, C.J.; Cordani, U.G.; González, H.; Weber, M.; Pelaez, C. (2006). Geochronological, isotopic, and geochemical data from PermoTriassic granitic gneisses and granitoids of the Colombian Central Andes. Journal of South American Earth Sciences, 21(4), 355-371. https:// doi.org/10.1016/j.jsames.2006.07.007

Weber, M.; Gómez-Tapias, J.; Cardona, A.; Duarte, E.; Pardo-Trujillo, A.; Valencia, V. (2015). Geochemistry of the Santa Fé Batholith and Buriticá Tonalite in NW Colombia - evidence of subduction initiation beneath the Colombian Caribbean Plateau. Journal of South American Earth Sciences, 62, 257-274. https://doi. org/10.1016/j.jsames.2015.04.002 
Worden, R.H.; Burley, S.D. (2003). Sandstone diagenesis: The evolution of sand to stone. In: S.D. Burley, R.H. Worden (eds.). Sandstone Diagenesis: Recent and Ancient (pp. 1-44). UK: Wiley-Blackwell. https://doi. org/10.1002/9781444304459.ch

Vinnels, J.S.; Butler, R.W.H.; McCaffrey, W.D.; Paton, D.A. (2010). Depositional processes across the Sinú Accretionary Prism, offshore Colombia. Marine and Petroleum Geology, 27(4), 794-809. https://doi.org/10.1016/j.marpetgeo.2009.12.008
Zapata-Villada, J.P.; Restrepo, J.J.; CardonaMolina, A.; Martens, U. (2017). Geoquímica y geocronología de las rocas volcánicas básicas y el Gabro de Altamira, Cordillera Occidental (Colombia): registro de ambientes de Plateau y arco oceánico superpuestos durante el cretácico. Boletín de Geología, 39(2), 13-30. https://doi. org/10.18273/revbol.v39n2-2017001

Trabajo recibido: octubre 10 de 2018

Trabajo aceptado: agosto 31 de 2020 